\title{
Interactions of Tailings \\ Leachate with Local Liner \\ Materials Found at \\ Canonsburg, Pennsylvania
}

M. E. Dodson

G. W. Gee

R. J. Serne

April 1984

Prepared for the U.S. Department of Energy

under Contract DE-AC06-76RLO 1830

Pacific Northwest Laboratory

Operated for the U.S. Department of Energy by Battelle Memorial Institute 


\title{
DISCLAIMER
}

This report was prepared as an account of work sponsored by an agency of the United States Government. Neither the United States Government nor any agency thereof, nor any of their employees, makes any warranty, express or implied, or assumes any legal liability or responsibility for the accuracy, completeness, or usefulness of any information, apparatus, product, or process disclosed, or represents that its use would not infringe privately owned rights. Reference herein to any specific commercial product, process, or service by trade name, trademark, manufacturer, or otherwise, does not necessarily constitute or imply its endorsement, recommendation, or favoring by the United States Government or any agency thereof. The views and opinions of authors expressed herein do not necessarily state or reflect those of the United States Government or any agency thereof.

\author{
PACIFIC NORTHWEST LABORATORY \\ operated by \\ BATTELLE \\ for the \\ UNITED STATES DEPARTMENT OF ENERGY \\ under Contract DE-AC06-76RLO 1830
}

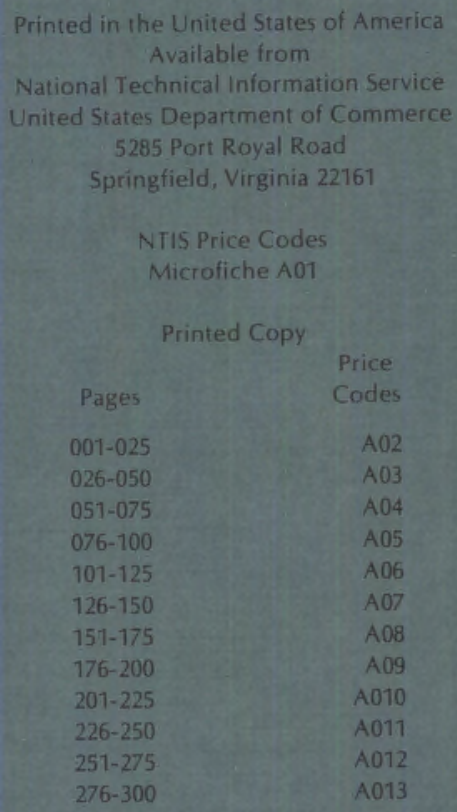


Juiy 31,1984

Pacific Northwest Laboratories P.O. Box 999

Richland, Washington U.S.A. 99352

Telephone (509)

Telex 15-2874

Recipients of PNL-5046; D0E/UMT-0219

Dear Recipients:

RE: Interactions of Tailings Leachates with Local Liner Materials Found at Canonsburg, Pennsylvania, Pacific Northwest Laboratory, Richland, WA April 1984

Please make the following changes in your copy of the subject. report:

Pages 6 and 9, Figure 1 and Figure 3 should be interchanged. The figure headings are correct.

Sincerely,

Muchuel \& Deriom

Michael E. Dodson

Senior Technician II

Geochemistry Section

MED/van 
DOE/UMT -0219

PNL -5046

UC -70

INTERACTIONS OF TAILINGS LEACHATE WITH

LOCAL LINER MATERIALS FOUND AT

CANONSBURG, PENNSYLVANIA

M. E. Dodson

G. W. Gee

R. J. Serne

Apri1 1984

Prepared for

the U.S. Department of Energy

Uranium Mill Tailings Remedial Action Program under Contract DE-AC06-76RLO 1830

Pacific Northwest Laboratory

Richland, Washington 99352 



\section{SUMMARY}

The mill tailings site at Canonsburg, Pennsylvania is the first 'mill site' to receive remedial action under the Department of Energy's (DOE) Uranium Mill Tailings Remedial Action Program (UMTRAP). Part of this remedial action will require excavating the $53,500 \mathrm{~m}^{3}\left(70,000 \mathrm{yd}^{3}\right)$ of tailings on the site having a specific activity exceeding $100 \mathrm{pCi} / \mathrm{g}$, and encapsulating these contaminated tailings in a clay-lined cell.

As part of of the remedial action effort, Pacific Northwest Laboratory (PNL) has been studying the interactions of tailings and tailings leachate with locally occurring clays proposed for liner materials. These studies include physical and chemical characterization of amended and unamended local clays, chemical characterization of the tailings, column studies of tailings leached with deionized water, and column studies of clays contacted with tailings solutions to determine the attenuation properties of the proposed liner materials.

Column studies of tailings leached with deionized water indicated that the Canonsburg tailings could represent a source of soluble radium-226 and uranium-238, several trace metals, cations, and the anions $\mathrm{SO}_{4}, \mathrm{NO}_{3}$, and $\mathrm{Cl}$. of these soluble contaminants, uranium-238, radium-226, the trace metals As and Mo, and the anions $\mathrm{F}$ and $\mathrm{SO}_{4}$ were present at levels exceeding maximum concentration levels (MCL) in the tailings leaching column effluents. However, local clays, both in amended and unamended form were effective in attenuating contaminant migration. Both amended and unamended clays removed high levels of trace metals and uranium-238, but were ineffective in removing the anions $\mathrm{SO}_{4}$, $\mathrm{NO}_{3}$, and $\mathrm{Cl}$ from the waste stream. Radium-226 was attenuated by the proposed clay liner materials, but the results were of such a tentative nature that we suggest further studies of the movement of radium through these local clays. The soil amendments tested failed to increase radium attenuation.

The tailings leaching studies indicated that the tailings will produce leachates of neutral $\mathrm{pH}$ and relatively low contaminant levels for at least 200 years. We believe that compacting the tailings within the encapsulation 
cell will help to reduce leaching of contaminants from the liner system, since very low permeabilities $\left(<10^{-8} \mathrm{~cm} / \mathrm{s}\right)$ were observed for even slightly compacted tailings materials. 


\section{ACKNOWLEDGEMENTS}

This study was funded by the U.S. Department of Energy as part of the Uranium Mill Tailings Remedial Action Program. The authors gratefully acknowledge the interest, helpful suggestions and encouragement provided by our colleagues at Pacific Northwest Laboratory, R. L. Erikson, W. J. Martin, B. E. Opitz and S. R. Peterson. We also express appreciation to M. M. Laegreid and M. M. Messmer, for their dedicated support in the collection of data for this study. Finally, thanks are given to J. L. Downs-Berg for editing this manuscript. 


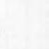


SUMMARY................................................... ii

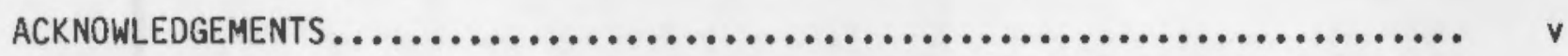

INTRODUCTION................................................ 1

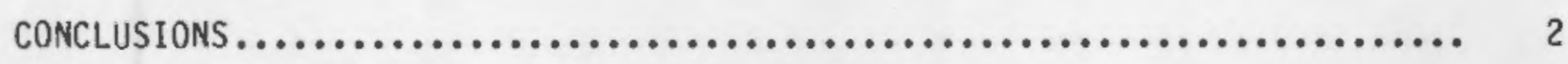

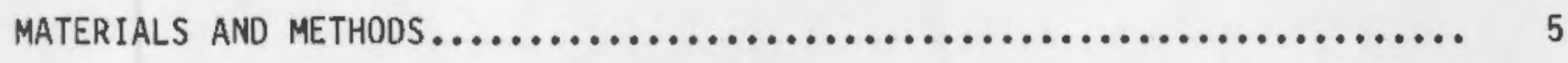

CHARACTERIZATION OF LOCAL CLAYS.......................... 5

SOLID TAILINGS CHARACTERIZATION........................... 8

SOLUTION ANALYSIS....................................... 10

COLUMN STUDY MATERIALS: SELECTION PROCEDURE.................. 12

COLUMN STUDIES OF CONTAMINANT ATTENUATION BY CLAYS $\ldots \ldots \ldots \ldots \ldots \ldots . . \ldots 13$

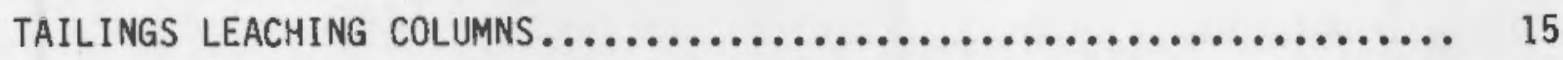

RESULTS AND DISCUSSION....................................... 16

PROPOSED LINER MATERIAL................................ 16

TAILINGS ANALYSIS $\ldots \ldots \ldots \ldots \ldots \ldots \ldots \ldots \ldots \ldots \ldots \ldots \ldots \ldots \ldots \ldots, 20$

PRODUCTION AND ANALYSIS OF TAILINGS LEACHATE: BATCH STUDIES....... 23

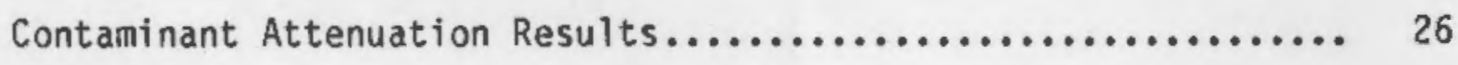

Macro Ions....................................... 30

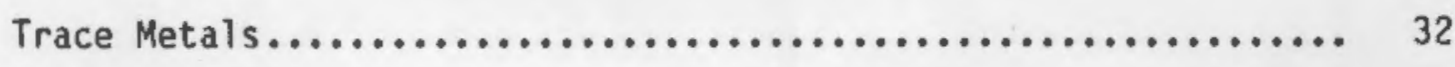

Uranium............................................... 33

Radium............................................. 33

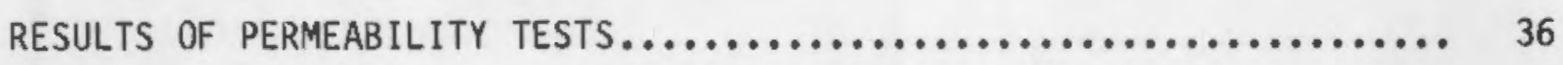

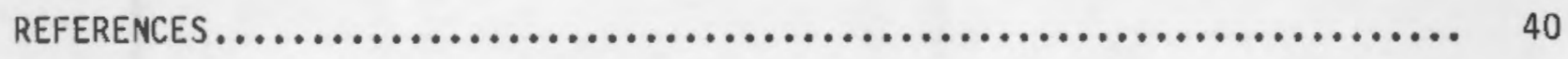


APPENDIX A - CHEMICAL ANALYSIS OF 1:1 WATER EXTRACTS FROM UNAMENDED AND IRON- AND MANGANESE-AMENDED COMPOSITES .............. A.I

APPENDIX B - CHEMICAL COMPOSITION OF ATTENUATION COLUMN ANO LEACHING COLUMN EFFLUENTS ........................ B.1 
FIGURES

1 Location of Proposed Borrow Area with Respect to the

Canonsburg Remedial Action Site............................... 6

2 Canonsburg Proposed Borrow Area Showing Test Borings and

Soil Sample Collection Locations............................... 7

3 Canonsburg Remedial Action Site Showing Tailings Collection

Locations.................................................. g

4 Moisture Density Relationship for Unamended Composite............. 20

5 Effluent $\mathrm{pH}$ Versus Pore Volumes for Attenuation

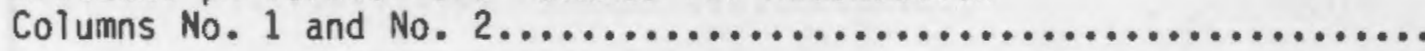

6 Effluent Concentrations of Aluminum Versus Pore Volumes

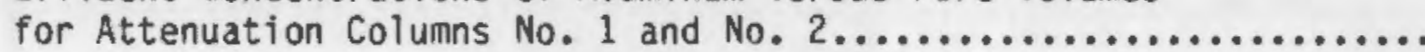

7 Concentration of Uranium Versus Pore Volumes for

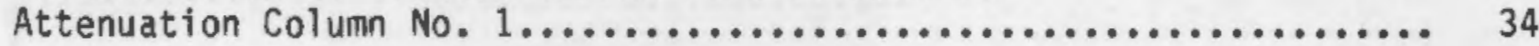

8 Concentration of Uranium Versus Pore Volumes for

Attenuation Column No. 2 .

\section{TABLES}

1 Description of Attenuation Columns........................... 15

2 Characteristics of Borrow Pit Materials...................... 17

3 Characteristics of the Three Canonsburg Liner Mixes.............. 19

4 Clay Mineral Percentages of Unamended Canonsburg Mix............. 20

5 Chemical and Radionuclide Concentrations of Solid

Canonsburg Tailings.......................................... 22

6 Characteristics of 1:1 Tailings Extracts and Tailings

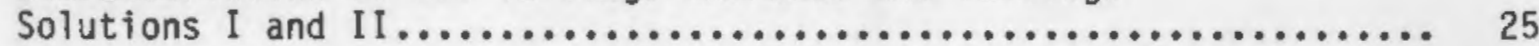

7 Maximum Concentration Levels for Drinking Water................ ?7

8 Chemical Analysis of 1:1 Water Extract from the Unamended Borrow Pit Liner Mix................................ 
9 Radium-226 Concentrations ( $\mathrm{pC} \mathrm{C} / \mathrm{L}$ ) Versus Pore Volumes for Attenuation Columns No. 1 and No. 2 and Leaching

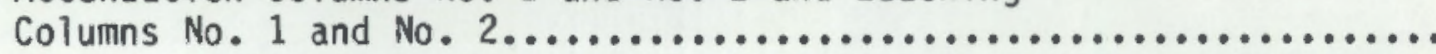

10 Permeability Results from the Attenuation and Leaching Columns

Plus Standardized Testing of the Unamended Composite

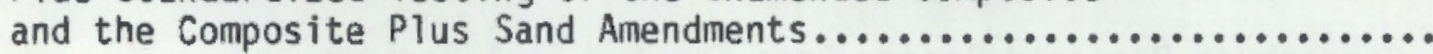

A.1 Chemical Analysis of 1:1 Water Extracts from Unamended and

Iron- and Manganese-Amended Composites.

B.1 Chemical Analysis of Effluent Solutions from Attenuation

Column No. 1 ...

B.2 Chemical Analysis of Effluent Solutions from Attenuation

Column No. 2......................................... B.2

B.3 Chemical Analysis of Effluent Solutions from Attenuation

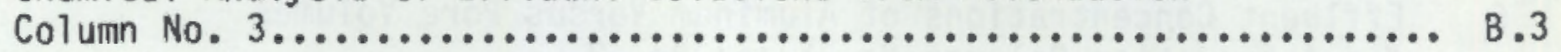

8.4 Chemical Analysis of Effluent Solutions from Attenuation

Column No. 4 ........................................... B.4

B.5 Chemical Analysis of Effluent Solutions from Attenuation

Column No. 5 ........................................ B.

8.6 Chemical Analysis of Effluent Solutions from Attenuation

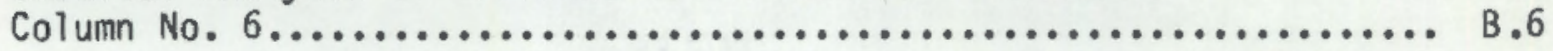

8.7 Chemical Analysis of Effluent Solutions from Leaching

Column No. 1, Tailings Mix 1, Produced from Tailings

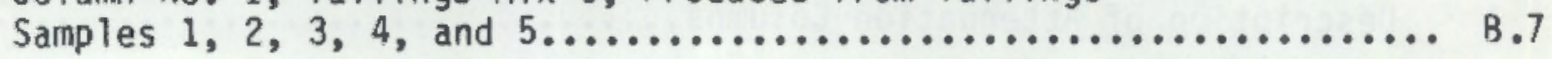

B.8 Chemical Analysis of Effluent Solutions from Leaching

Column No. 2, Tailings Mix II, Produced from Tailings

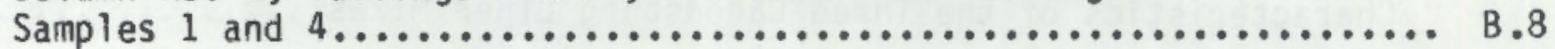




\section{INTRODUCTION}

The uranium mill tailings sites at Canonsburg, Pennsylvania, are the first of nine high priority sites scheduled for remedial action (DOE 1982). Remedial action at Canonsburg will require relocation of some of the tailings on site. The present design calls for placement of these tailings within a containment system using a natural earthen liner system. High levels of rainfall at the Canonsburg site- dictate that the liner should not allow accumulation of leachate. Rather, the liner system should serve as a backup for the cover system, acting as a flow-through attenuation medium for any contaminants that leach from the tailings. This study evaluates the leachate-soil interactions that will take place at Canonsburg if unamended local clays or either iron oxide or manganese-saturated zeolite-amended composites are used in the liner system. The following laboratory tests were conducted:

1. The local clay liner materials in both unamended and amended forms were physically and chemically characterized. Amendments included either $2 \%$ (dry-weight basis) iron oxide or $2 \%$ manganese-saturated green-sand zeolite.

2. The solid tailings present at the Canonsburg site and the water soluble extracts produced from these tailings were chemically characterized.

3. Solid tailings were leached with deionized water in column leaching studies to evaluate the movement of water soluble contaminants from the tailings with time.

4. The unamended and amended local clays were contacted with two tailings leachate solutions in column attenuation studies. Solution I represented an equal mixture of the water soluble extracts produced from each tailings sample received from the Canonsburg site, and solution II was composed of the water soluble extracts from the two most heavily contaminated tailings samples. These studies allowed us to predict the long-term compatibility of the proposed liner materials with representative tailings leachates and to measure their attenuation characteristics for heavy metals, radionuclides, cations, and anions. 


\section{CONCLUSIONS}

Six individual clay samples taken from the proposed borrow pit area had similar physical characteristics and chemical properties. All samples were fine textured (>66\% silt and clay) and possessed a relatively high cation exchange capacity (>14 meq/100 g). This implied that any combination of three or more of these proposed liner materials in a final liner mix would produce near identical composites.

Of the five tailings samples taken, two samples contained elevated concentrations of anions and trace metals, sulfate, nitrate, fluoride, arsenic, copper, nickel, and lead. High-resolution gamma counting confirmed that these two tailings samples were also high in radium and uranium compared to the other three tailings samples. Analyses of $1: 1$ water extracts from each tailings sample supported these results.

The neutral pH of the solid tailings resulted in very limited release of most contaminants from the tailings during the production of $1: 1$ water extracts. Even the 1:1 extracts produced from the two tailings samples with elevated concentrations contained concentrations of most trace metals that approached analytical detection limits and radionouclide concentrations several orders of magnitude below those in the solid tailings.

Those contaminants in the tailings extracts showing concentrations high enough to cause environmental concern included uranium-238, radium-226, arsenic, molybdenum, sulfate and nitrate. Data from column leaching studies with deionized water and solid tailings support the data generated from batch extraction studies, and suggest that radium-226 presents the greatest long-term leaching hazard at the Canonsburg site.

Both the amended and unamended local clay composites were very effective in retarding the movement of uranium-238 and the trace metals present in the waste streams. However, the composites were unable to attenuate, and actually may have increased selected cation and anion concentrations. One exception was the retardation of the anion $\mathrm{NO}_{3}$ after $\sim 2.0$ pore volumes were passed through the column. 
Radium-226 attenuation results were inconsistent. One unamended liner column showed favorable Ra removal, but another displayed results that indicate additional additives may be necessary to attenuate radium movement from the encapsulated tailings. General results indicated that adding either iron oxide or a manganese-coated zeolite did not reduce radium migration compared to the reduction achieved with native iron and manganese oxides, which are found as particle coatings on the silicate minerals of the unamended Canonsburg liner material. Although not fully tested, the salts of barium could provide the attenuation of radium needed. Particularly intriguing is that the liner column experiencing the highest influx of radium displayed not only greater attenuation, but also lower effluent concentrations by a factor approaching 10, than the liner column contacted with influent solution that had reduced radium concentrations. These results suggest that a closer investigation of the behavior of the chemical properties of radium in both the tailing solutions and liner system are needed.

Because rainfall exceeds evapotranspiration for much of the year at the Canonsburg site, an impermeable cap must be placed over the waste or the permeability of the liner must be high enough to allow excess water to drain from the encapsulation cell, otherwise a 'bathtub effect' is created that can cause near surface seepage. Permeability (hydraulic conductivity) measurements of the unamended soil composite showed its hydraulic conductivity to be very low $\left(\sim 10^{-8} \mathrm{~cm} / \mathrm{s}\right)$. Furthermore, 5 and $10 \%$ amendments with sand failed to significantly increase the permeability of the unamended composite. However, hydraulic conductivity measurements of the solid tailings, after only slight compaction, showed hydraulic conductivity to be no greater than $10^{-8} \mathrm{~cm} / \mathrm{s}$. Under conditions where significant infiltration $(>1 \mathrm{~cm} / \mathrm{yr})$ would occur at the waste site, excess water may pool on top of the tailings rather than penetrating them and interacting with the liner. An alternate encapsulation design is suggested that uses coarse material to surround both the compacted liner and cover. This design would divert water away from the waste. Surface seepage would be prevented unless the ground-water table fluctuated sufficiently to rise above the base of the tailings pile. 
The high residual water content and low hydraulic conductivity of the solid tailings may result in both relocation and encapsulation difficulties. Because we lack water-retention (drainage) data for the tailings, it is hard to predict the amount of leachate that will be produced from the water present in the tailings alone. Additional studies on water retention characteristics and the permeability relationships as a function of tailings compaction would be helpful to evaluate the leachability of the tailings material. If the tailings are tightly compacted, leachate movement from the tailings might be controlled by diffusion. This would result in very limited movement of leachate from the tailings.

Predictions using estimates of liner permeability and thickness and expected hydraulic head conditions, coupled with column data indicate that the unamended liner material will not degrade under waste leachate attack for at least several hundred years. 
MATERIALS AND METHODS

CHARACTERIZATION OF LOCAL CLAYS

This section outlines the materials and methods used to physically and chemically characterize the local clays proposed for liner materials and the Canonsburg tailings. Also included are descriptions of the column studies used to determine the attenuation properties of the proposed liner materials and to determine the quality of leachate escaping the liner.

Before investigating the compatibility of leachate from waste materials to be encapsulated at the Canonsburg site with a local liner material, six individual soil samples were removed from the proposed borrow pit area for physical testing. The location of the proposed borrow pit site with respect to the Canonsburg remedial action site is shown in Figure 1 . The proposed borrow pit area, the approximate locations of test borings conducted in December 1982, and the six sampling areas in the borrow pit are shown in more detail in Figure 2. The numbers assigned to each sampling area in Figure 2 represent Pacific Northwest Laboratory's (PNL) designated sampling code and follows the sampling code provided by National Lead of Ohio (NLO), who collected, packaged and shipped the soil samples to PNL.

Samples were taken by backhoeing to a depth of 1.5 to $3 \mathrm{~m}$ ( 5 to $10 \mathrm{ft}$ ), placing the spoils at ground level adjacent to each site, and choosing 34 to $45 \mathrm{~kg}$ (75 to $100 \mathrm{lb}$ ) subsamples from each spoils pile being represented.

Upon receipt at PNL, samples were logged in and measured for field water content before being air dried to allow each bulk sample to be reduced to less than $5-\mathrm{cm}\left(2-i n_{.}\right)$size fractions. At this point, all remaining sample fractions not easily reduced to less than $5 \mathrm{~cm}$ (2 in.) were discarded. Samples were next subsampled by quartering and each subsample tested for physical properties including particle size distribution, particle density, and plasticity indexes. All physical analyses were conducted using standard ASTM (1982) methods. 
CANONSBURG SITE

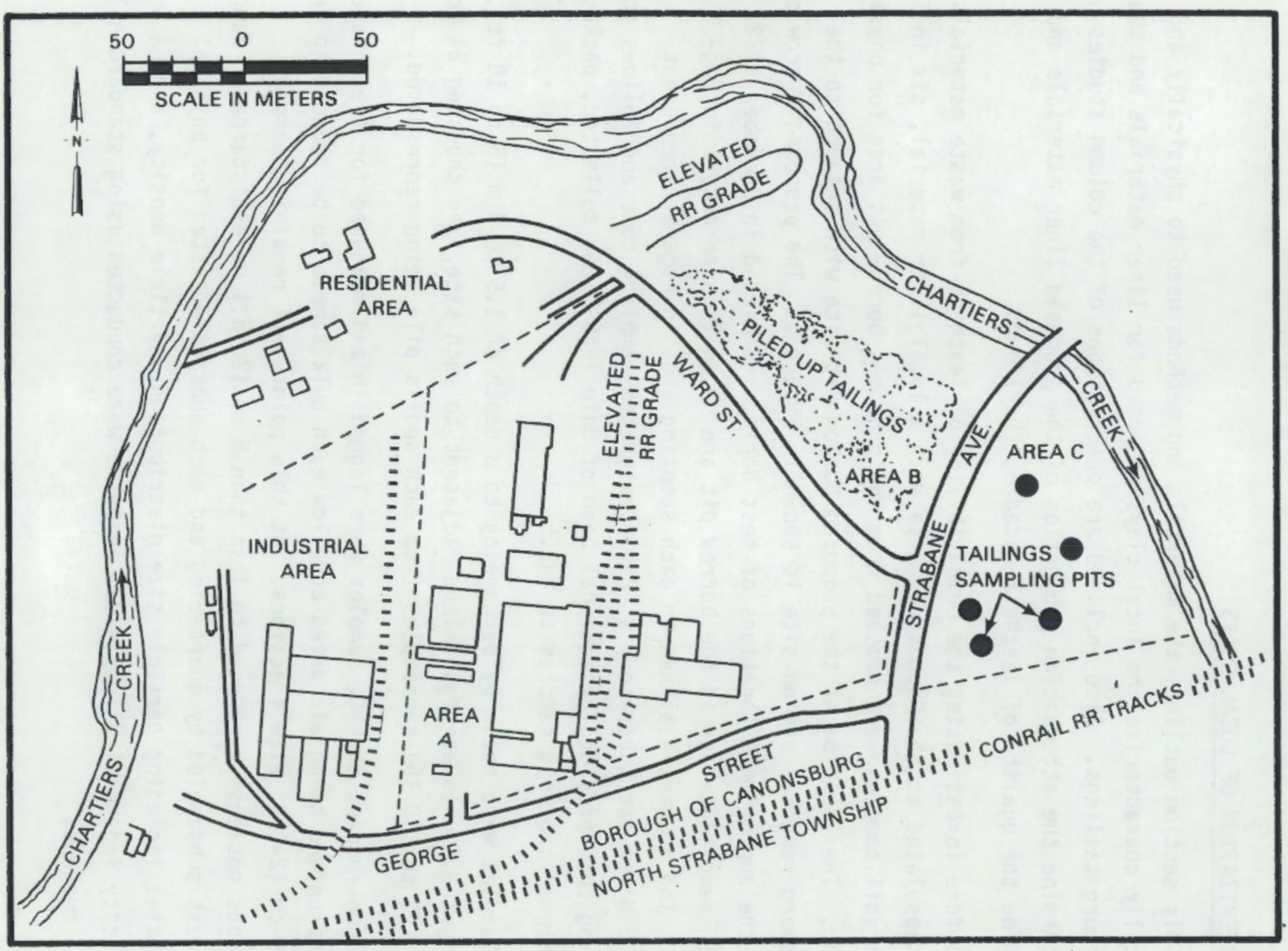

FIGURE 3. Location of Proposed Borrow Area with Respect to the Canonsburg Remedial Action Site 


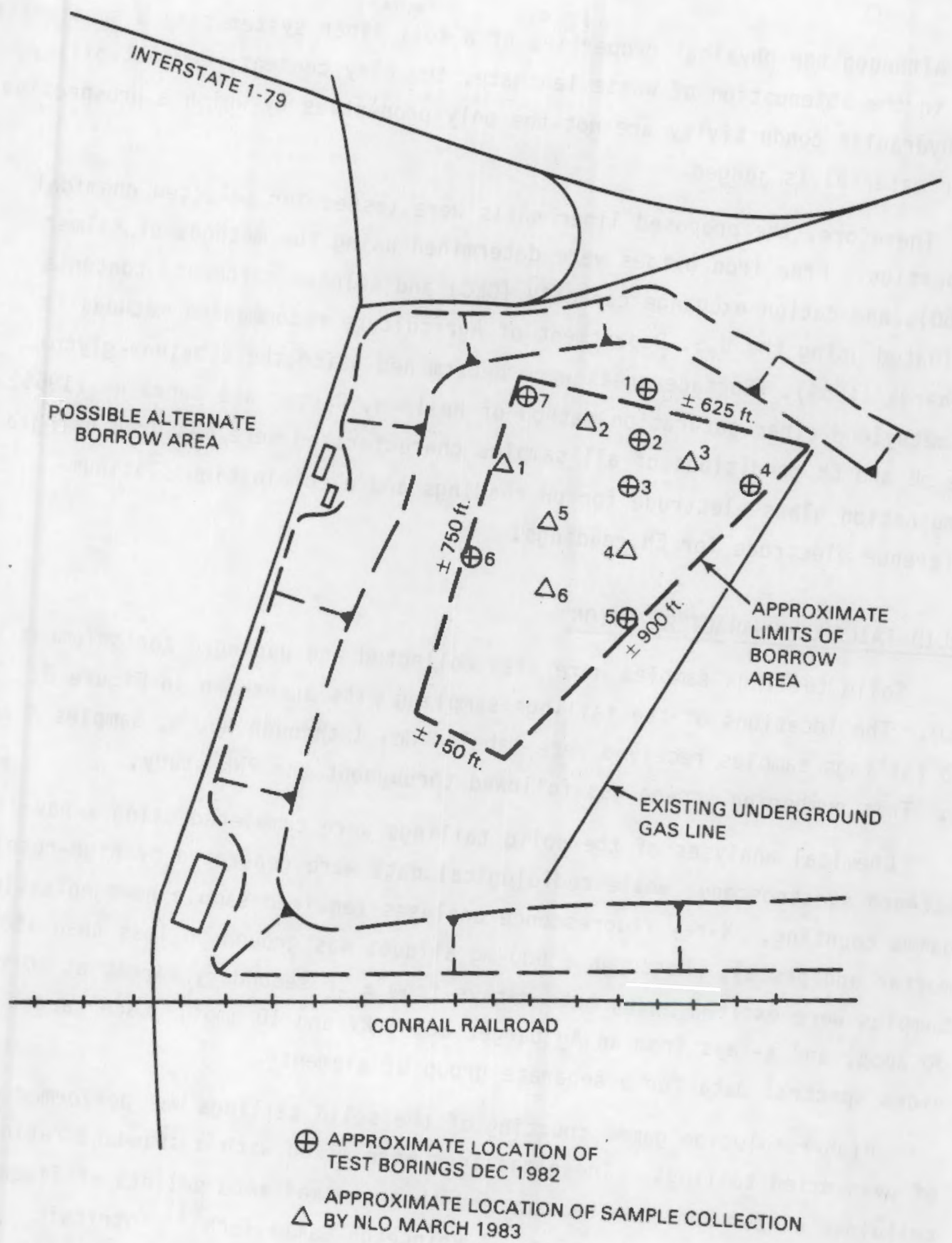

FIGURE 2. Canonsburg Proposed Borrow Area Showing Test Borings
and Soil Sample Collection Locations 
Although the physical properties of a soil liner system play a substantial role in the attenuation of waste leachate, the clay content, compactability, and hydraulic conductivity are not the only properties by which a prospective liner material is judged.

Therefore, the proposed liner soils were tested for selected chemical properties. Free iron oxides were determined using the methods of Kilmer (1960), and cation exchange capacity (CEC) and calcium carbonate contents evaluated using the U.S. Department of Agriculture recomriended methods in Richards (1954). Surface areas were determined using the ethylene glycol monoethylene ether saturation method of Heilman, Carter and Gonzales (1965). The $\mathrm{pH}$ and Eh conditions of all samples characterized were measured using a combination glass electrode for $\mathrm{pH}$ readings and a combination platinumreference electrode for Eh readings.

\section{SOLID TAILINGS CHARACTERIZATION}

Solid tailings samples were also collected and packaged for shipment by NLO. The locations of the tailings sampling pits are shown in Figure 3 . The 10 tailings samples received were labeled No. 1 through No. 5, Samples A and B. This numbering scheme was followed throughout the PNL study.

Chemical analyses of the solid tailings were completed using $x$-ray fluorescence spectroscopy, while radiological data were generated by high-resolution gamma counting. X-ray fluorescence analyses required sample homogenization by mortar and pestal, whereupon a 600-mg aliquot was ground to less than 150 mesh. Samples were excited using both x-rays from a $\mathrm{Zr}$ secondary target at $40 \mathrm{kV}$ and 30 amps, and $x$-rays from an Ag target at $45 \mathrm{kV}$ and 10 amps. Each target provides spectral data for a separate group of elements.

High-resolution gamma counting of the solid tailings was performed on $5 \mathrm{~g}$ of oven dried tailings. These tailings were mixed with a standard ratio of a cellulose binder and dunnite sand and then pressed into pellets of fixed geometry to ensure accurate counting. A Princeton Gamma-Tech(a) intrinsic germaniuim diode, coupled with a Nuclear Data ND6620 Nuclear Analyzer ${ }^{\circledR}$, was used to analyze samples for uranium-238 and three of its daughter products: lead-210, thorium-230, and radium-226. Radionuclide concentrations were 


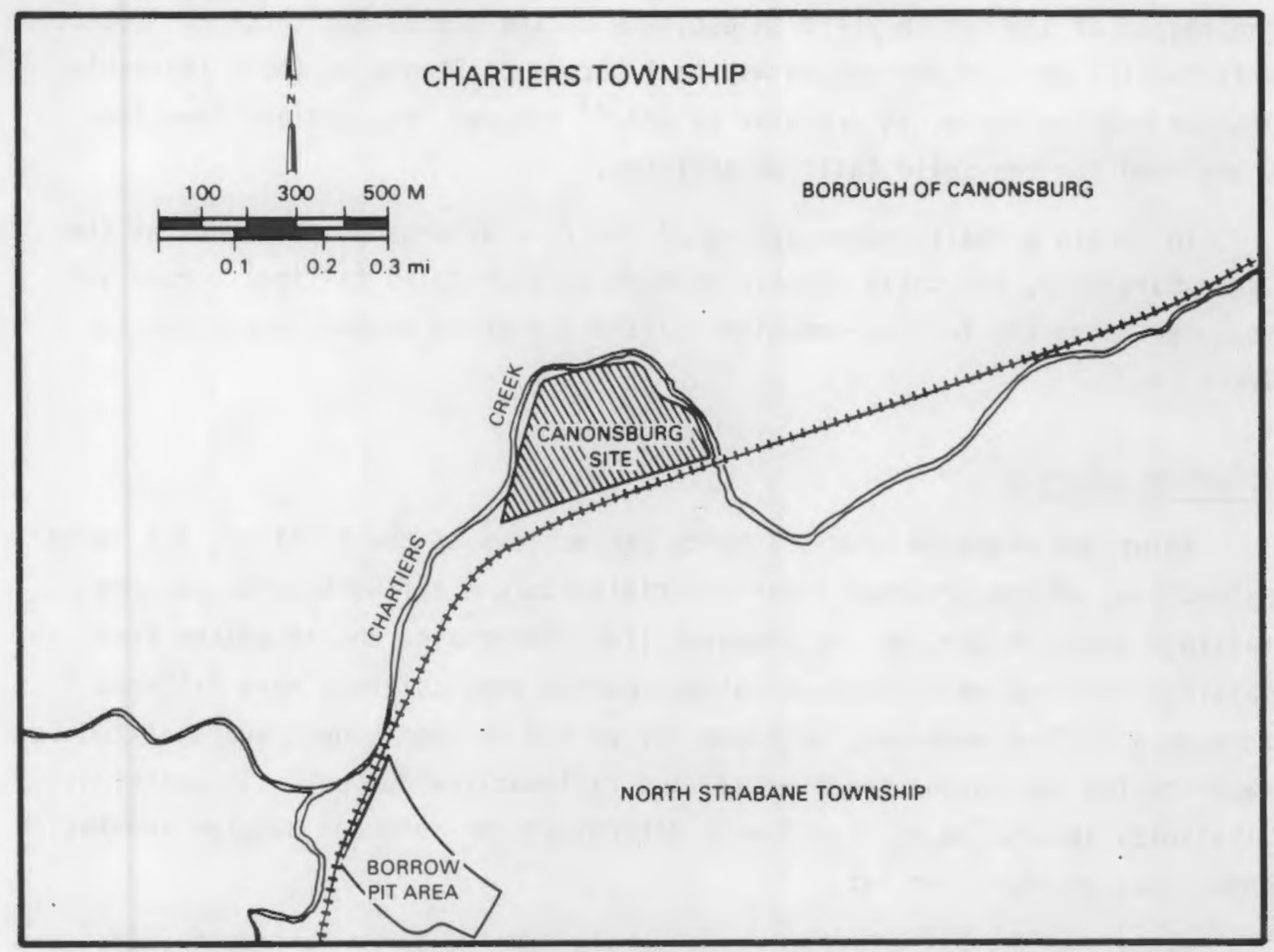

FIGURE 1. Canonsburg Remedial Action. Site Showing Tailings Collection Locations

determined over a counting time of seven hours using gamma intensities of 46.5 , $63.3,67.7$, and $185.8 \mathrm{KeV}$, for 1ead-210, uranium-238, thorium-230, and radium-226, respectively. The $238 \mathrm{U}$ activity is actually based on counting a gamma ray $(63.3 \mathrm{KeV})$ of its daughter product ${ }^{234} \mathrm{Th}$. The radium-226 activity is calculated after correction of the count rate of the $185.8 \mathrm{KeV}$ peak for a contribution from uranium-235, which also has a gamma ray (183.7 KeV) nearby. The correction factor is based on the ratio of $238 \mathrm{U} /{ }^{235} \mathrm{U}$ activity found in natural ore deposits $(21.5)$. Thus, upon calculation of the ${ }^{238} \mathrm{U}$ content, an activity for $235_{\mathrm{U}}$ may be calculated and subtracted from the total activity in 
the region of $185 \mathrm{KeV}$ to yield an estimate of the radium-226 content. Detector efficiencies were determined on National Bureau of Standards (NBS) traceable uranium-bearing sediments prepared by EPA(a) pressed into pellets identical to those used for the solid tailings analyses.

To obtain a small understanding of the role of organic compounds at the Canonsburg site, the total organic content of each solid tailings sample was measured using the ferrous-ammonium-sulfate titration method (Alexander and Byers 1932).

\section{SOLUTION ANALYSIS}

Solutions produced from 1:1 batch extractions of the tailings, 1:1 batch extractions of the proposed liner materials, column effluents from passing tailings solution through the proposed liner materials, and leachates from passing deionized water through columns packed with tailings were filtered through a 0.45- $\mathrm{mm}$ membrane, measured for $\mathrm{pH}$ and Eh conditions, and analyzed for major cation and anion, trace metal, and radionuclide content. In addition, alkalinity levels (as $\mathrm{mg} \mathrm{CO}_{3} / \mathrm{L}$ ) were determined for selected samples showing $\mathrm{pH}$ conditions greater than 4.5 .

Major cations and selected trace metals were measured by inductively coupled argon plasma emission spectrometry (ICP), using standard procedures recommended for the 925 Jarrell-Ash(b) ICP unit. The low salt content of all liquid samples allowed them to be run direct with limited spectral interferences.

The trace metals (As, Cd, Co, Cr, Mn, Mo, Pb, and Se) were determined using graphite furnace atomic absorption (AA/GF) on a Perkin Elmer(C) Model 5000 and HGA-5000 graphite furnace. The matrix interferences common to such heterogenous solutions were compensated for by diluting the sample until known addition spikes showed at least $80 \%$ recovery as compared to additions to deionized water. The analysis of $A s$ and $S e$ also required a nickel-based matrix modification (Ediger 1975; Martin et a1. 1975). For lead analysis, the

\footnotetext{
(a) U.S. Environmental Protection Agency, Environmental Monitoring and Support Laboratory - Las Vegas, Quality Assurance Branch.

(b) Jarrell-Ash, a division of Fischer Scientific, Co. Pittsburg, Pennsylvania.

(c) Perkin Elmer, Norwalk, Connecticut.
} 
platform method suggested by Slavin and Manning (1979) was employed. Serne, Peterson, and Gee (1983) found that these analytical methods provide accurate determinations of the trace metals contained in acidic uranium mill tailing solutions, and these methods currently are routinely employed in the analysis of liquid samples presenting any matrix problems. All samples analyzed by ICP and $\mathrm{AA} / \mathrm{GF}$ were preserved with redistilled $\mathrm{HNO}_{3}$ to give a final $\mathrm{pH}$ of 2 . Anion concentrations were measured on undiluted samples using a Dionex Auto Ion model 12S, while alkalinity was determined by titration with standard $(0.01 \mathrm{~N})$ $\mathrm{H}_{2} \mathrm{SO}_{4}$.

Pulsed laser fluorimetry determination of solution uranium contents was necessary because the uranium concentrations were low even in the 1:1 solid tailings batch extract solutions. Although the technique is very sensitive (detection limit is $0.0005 \mu \mathrm{g} / \mathrm{mL}$ ), the low uranium content of several of the column effluent samples precluded large dilutions, resulting in matrix interferences. It must be noted that these problems were found only in the samples with very low uranium concentrations. If matrix problems were encountered, reported uranium values would be biased high.

Radium-226 concentrations were determined on liquid samples using alpha scintillation. This method of radium analysis included filtering the samples and adding a stable barium carrier and potassium in the form of chloride. Next, using heat and sulfuric acid, a $\mathrm{BaSO}_{4}$ precipitate was formed. After centrifuging and washing, the precipitate was redissolved in DTPA and piperdine, which chelated not only barium and radium, but also any heavy metals present in the solution. The precipitate was reformed by adjusting the solution $\mathrm{pH}$ and sulfate content to allow the removal of only barium and radium. The time at which the reprecipitation was completed is referred to as the time of separation. After centrifuging and washing, the precipitate was mounted on a planchet, dried, weighed, and ignited. The time of final ignition was used as a reference time to calculate the ingrowth of radon and its short-lived daughter products before counting. All counts were completed within 200 min of separation time to limit interferences from daughter alpha sources. Counting

- Registered trademark of the Dionex Corporation, Woodbridge, New Jersey. 
was performed on a zinc sulfide scintillation counter that was calibrated for efficiency as a function of precipitate weight.

\section{COLUMN STUDY MATERIALS: SELECTION PROCEDURE}

Rather than arbitrarily mixing the individual samples from the proposed borrow pit to form a composite, each sample was individually characterized to determine if the systematic use of soils from specified sections of the borrow pit could produce a superior liner composite. The decision on the final composite mix was reached by considering the variability of the basic classification properties exhibited by each sample, including particle size distribution, particle density and plasticity indexes, plus the chemical attributes of each soil that were favorable to the attenuation of contaminant migration.

The final Canonsburg liner mix was prepared by homogenizing the sample on a mixing canvas and quartering after the over 5-cm (2-in.) size fraction had been removed. This method allowed us to produce a representative sample in lots of a workable size (approximately $20 \mathrm{~kg}$ ). Along with retesting the physical and chemical parameters of the unamended mixture as described for the individual soil samples, moisture density relationship (proctor testing) and bulk clay mineralogy data were collected. Proctor testing was conducted using the standard American Society for Testing and Materials (ASTM) (1557-D) method (ASTM 1982). Quantitative clay mineralogy analyses were performed by Dr. Murray Klages of Montana State University, Bozeman, Montana. His methods of analyses include dispersion and removal of flocculated clays by standard sodium hexametaphosphate and centrifuging techniques. Mounted paste slides of magnesium-saturated clays were glycolated before $x$-ray analyses. The presence of a $14 \AA$ peak also required that potassium-saturated slides also be analyzed. The disappearance of the $14 \AA$ peak only upon heating of the potassium-saturated slides indicated the presence of a vermiculite chlorite with considerable illite interstratification. Mineral percentages of the clay fraction were arrived at using the peak adjustment factors for converting diffraction peak areas to mineral percentages found in Klages and Hopper (1982).

Production of tailings solution in large quantities was preceded by smallscale tailings extraction studies. Deionized water was placed in contact with 
each solid tailings sample under batch extraction conditions. In an effort to avoid diminishing the role of volatile organic compounds presumably present in the solid tailings, samples were maintained at field moisture conditions before the start of all extraction and leaching studies involving tailings. Batch extraction consisted of contacting $500 \mathrm{~g}$ of solid tailings with $500 \mathrm{~mL}$ of water in sealed polyethylene bottles. Contact was allowed to continue for 3 days, with constant shaking to promote mixing. The field water content of each tailings sample was measured, and batch-study sample weights corrected to oven dried values. In addition, the calculated initial sample pore water volume was included in the total volume of contact solution. Upon completion of the 3-day contact period, the supernatants were filtered and split into six aliquots. One aliquot was measured for $\mathrm{pH}$ and $\mathrm{Ch}$ conditions and the remaining five aliquots were analyzed for trace metal, cation, anion, and radionuclide content.

\section{COLUMN STUDIES OF CONTAMINANT ATTENUATION BY CLAYS}

Construction of columns to evaluate contaminant attenuation entailed uniformly packing proposed liner material into the top half $(4.4 \mathrm{~cm})$ of $\mathrm{clear}$ lexan cylinders measuring $8.8 \mathrm{~cm}$ in length and $13.8 \mathrm{~cm}$ in diameter. The bulk density of the liner material in each column was fixed at $1.60 \mathrm{~g} / \mathrm{cm}^{3}(75 \%$ of proctor) providing a soil pore volume of $280 \mathrm{~mL}$. The pore volume of soil is equal to the product of the calculated soil porosity and the volume of soil. Because the entire column was not filled with the proposed clays, the calculated soil pore volume is not a true column pore volume. However, for convenience the calculated soil pore volume will be referred to as a column pore volume in all following discussions and calculations.

Only a portion of each column was filled with liner material in order to reduce pore volume sizes, tailings solution needs, and to adjust flux times to workable limits. The bottom half of each column was subsequently filled with glass beads to prevent swelling or sagging of the liner materials. A layer of nylon screen was placed at the soil glass-bead interface and the column inlets and outlets to prevent particle migration. 
Tailings solution was passed through the columns using a constant pressure head system maintained by a mariotte flask. Such constant head systems have advantages over pump systems in that individual column flow rates may be adjusted precisely while using a single leachate reservoir, and very small changes in column permeabilities may be measured accurately (Gee et al. 1980). All leachate flow was from column bottom to top, ensuring saturated conditions, while leachate flux was regulated to a speed of approximately 0.25 pore volume per day. Effluents were collected every 0.25 pore volume for the first pore volume and every 0.5 pore volume for the remaining 2 pore volumes. This flow rate was deemed slow enough to allow reasonable contact periods of tailings solution with liner material and still provide effluent samples in a timely manner. Although flow rates can be controlled precisely in column studies, there are problems in representing field conditions using small samples. Precise replication of results, even among a series of identical columns, is difficult even if standardized packing methods are employed. Pore distribution, trapped air, and flow through fractures and along column walls complicate column experiments. To minimize these problems, any column showing unusual flow behavior was dismantled, repacked using fresh liner material and restarted.

The six liner columns used in the attenuation studies are described in Table 1. Selection, production, and characterization of the clay composites and tailings solutions for these column studies are discussed in other sections.

In addition to monitoring column flow rates throughout all column studies, precise hydraulic conductivity measurements were conducted, using tap water, on each clay composite tested. Rainfall at the Canonsburg area exceeds evapotranspiration for much of the year and may cause ponding on the liner. Because the possibility of a 'bathtub effect' after tailings encapsulation must be eliminated, we investigated the increase in hydraulic conductivity of the unamended clay composite when sand was added at 5 and $10 \%$ by weight. Hydraulic conductivity measurements were performed under saturated conditions using the falling head methods described in Black (1965). 


\section{TABLE 1. Description of Attenuation Columns}

\begin{tabular}{|c|c|c|c|}
\hline $\begin{array}{c}\text { Column } \\
\text { No. }\end{array}$ & Proposed Liner Material & $\begin{array}{l}\text { Column Dry- } \\
\text { Weight Bulk } \\
\text { Density, } \mathrm{g} / \mathrm{cm}^{3} \\
\end{array}$ & Contact Solution \\
\hline 1 & Clay composite & 1.60 & Solution II \\
\hline 2 & Clay composite & 1.60 & Solution I \\
\hline 3 & Composite $+2 \%$ iron oxide & 1.60 & Solution II \\
\hline 4 & Composite $+2 \%$ iron oxide & 1.60 & Solution I \\
\hline 5 & Composite $+2 \%$ Mn zeolite & 1.60 & Solution II \\
\hline 6 & Composite $+2 \%$ Mn zeolite & 1.60 & Solution I \\
\hline
\end{tabular}

TAILINGS LEACHING COLUMNS

Each column leaching study was conducted using a different ratio of solid tailings and deionized water as the leaching solution. Column No. 1 contained equal weights of solid tairings from samples $1 A, 2 A, 3 A, 4 A$ and $5 A$, while Column No. 2 contained equal weights of solid tailings from samples $1 A$ and $4 A$ only. As will be discussed in subsequent sections, leachate from leaching Column No. 1 should closely represent the actual tailings leachate found at the Canonsburg site while effluent from leaching Column No. 2 represents a worstcase leaching scenario. As in the tailings batch extraction studies, care was taken to ensure that the tailings were compacted into each column without the loss of field moisture. Thus, dry-bulk density data for these columns are calculated rather than measured.

Columns used in the tailings leaching study were clear lexan cylinders $8.9 \mathrm{~cm}$ in diameter and $8.9 \mathrm{~cm}$ in length. Tailings were compacted into the entire volume of each column at a fixed dry-bulk density of $1.30 \mathrm{~g} / \mathrm{cm}^{3}$, giving a column pore volume of $292 \mathrm{~mL}$. Flow through the columns was from column bottom to top. A constant pressure head was provided by a pressurized influent storage reservoir, because the permeabilities of the tailings were found to be very low even though the dry-bulk density was only $1.30 \mathrm{~g} / \mathrm{cm}^{3}$. Pressure was maintained between 1 to 2 bars $(1,020$ to $2,040 \mathrm{~cm})$ throughout the study. Effluent sampling was conducted on the same schedule used to collect effluents in attenuation column studies. 


\section{RESULTS AND DISCUSSION}

\section{PROPOSED LINER MATERIAL}

Selected physical and chemical properties of the six liner samples are presented in Table 2. The Unified Soil Classification System places the proposed liner materials in either the ML or CL groups. These classification groups represent clay silts with slight plasticity or sandy clays with low to medium plasticity, respectively. This matches closely the data provided by W. A. Ericson, (memo from Jacobs-Weston Team, Albuquerque, New Mexico, to PNL dated Apri1 18, 1983) from the 1982 test borings of the borrow pit area (Figure 2). Ericson's data, from visual and laboratory investigations of auger cores, indicated that the top $15 \mathrm{ft}$ of the borrow pit area contains very weathered shale of medium plasticity, which may represent open pit mine backfill. Classification in the laboratory determined samples from bore holes No. 2 and No. 5 to be sandy clays (CL) and to contain 20 and $25 \%$ clay, respectively.

The CEC and free iron oxide contents in Table 2 suggest that the liner materials have a significant capacity for contaminant attenuation through adsorption reactions. Iron oxides appearing as coatings on soil particles often influence attenuation of trace metals and radionuclides beyond predictions based on their molar concentrations in the soil matrix (Jenne 1968). On the other hand, the low calcium carbonate concentrations and $\mathrm{pH}$ values common to all six liner samples would tend to rule out acid-buffering-induced precipitation reactions as an important attenuation mechanism for these materials.

Based on the data from Table 2, the small differences in soil properties inherent to the six individual samples of local clay implies that any combination of three or more of these liner materials in a final liner mix would produce near identical composites. Thus, a final Canonsburg liner mix was prepared for column attenuation studies using equal weight portions of all six liner samples.

In addition to characterizing the unamended liner mixture, two amended mixtures were fully characterized, except for proctor testing and clay mineral composition. The two amended mixtures represent the proposed liner plus 
TABLE 2. Characteristics of Borrow Pit Materials

\begin{tabular}{|c|c|c|c|c|c|c|c|c|c|c|c|c|c|}
\hline Sample & $\begin{array}{c}\begin{array}{c}\text { Unified } \\
\text { Soil } \\
\text { Classification } \\
\text { Systein }\end{array} \\
\end{array}$ & $\begin{array}{l}\text { Liquid } \\
\text { Limit } \\
\end{array}$ & $\begin{array}{l}\text { Plastic } \\
\text { Limit } \\
\end{array}$ & $\begin{array}{c}\text { Plasticity } \\
\text { Index } \\
\end{array}$ & $\begin{array}{l}\text { Particle } \\
\text { Density, } \\
\mathrm{g} / \mathrm{Cln}^{\circ} \\
\end{array}$ & $\begin{array}{c}\text { Clay. } \\
\text { I. }\end{array}$ & $\begin{array}{c}\text { Sand, } \\
1\end{array}$ & silt, & $\begin{array}{l}\text { pH Soil } \\
\text { Paste, } \\
\text { pH Units }\end{array}$ & $\begin{array}{l}\text { En 1:1 } \\
\text { Extract, } \\
+\quad \text { my } \\
\end{array}$ & $\begin{array}{r}\text { Cation } \\
\text { Exchange } \\
\text { Capacity, } \\
\text { meg/100g } \\
\end{array}$ & $\begin{array}{c}\text { Calcium } \\
\text { Carbonate } \\
\text { Content, } \\
\quad \$ \\
\end{array}$ & $\begin{array}{c}\text { Free Iron } \\
\text { 0xide } \\
\text { Content, } \\
\quad \Sigma \\
\end{array}$ \\
\hline 1 & ML. & 32 & 24 & B & 2.76 & 30 & 16 & 54 & 4.54 & 573 & 16.0 & 0.31 & 0.21 \\
\hline 2 & ML. & 32 & 31 & 1 & 2.77 & 20 & 14 & 66 & 4.47 & 624 & 16.0 & 0.11 & 0.20 \\
\hline 3 & $\mathrm{ML} / \mathrm{CL}$ & 28 & 21 & 7 & 2.76 & 19 & 26 & 55 & 4.37 & 515 & 14.2 & 0.12 & 0.18 \\
\hline 5 & ML & 30 & 24 & 6 & 2.63 & 17 & 31 & 52 & 4.82 & 560 & 17.5 & 0.09 & 0.26 \\
\hline 6 & ML. & 29 & 26 & 3 & 2.75 & 15 & 33 & 52 & 4.66 & 508 & 14.3 & 0.21 & 0.27 \\
\hline
\end{tabular}


either a $2 \%$ (dry-weight basis) addition of crystalline iron oxide or manganesecoated zeolite. Iron oxides were added in the form of a reagent grade chemical and the manganese additive represented a manganese-saturated zeolite sold under the trade name of Ferro Sand $\$$. The purpose of the iron oxide and manganese zeolite additions was to test for an enhancement of the contaminant attenuation properties of the natural borrow pit materials through adsorption and coprecipitation reactions (Jenne 1968; Korte et al. 1975; Fuller 1981). Selected physical and chemical characteristics of these three liner materials are given in Table 3. The proctor (bulk density versus moisture content) values of the unamended borrow pit liner composite are shown in Figure 4; bulk clay mineral percentages for this composite are given in Table 4 .

In the past, the Environmental Protection Agency (EPA 1978) has proposed criteria for soil or amended soil materials that are to be considered for use as a liner for hazardous waste disposal. Several of these criteria were tested while characterizing the proposed Canonsburg liner composite and the iron or manganese amended mixes. With the exception of soil pH, these liner composites closely conformed to the EPA requirements of having a soil classification of $\mathrm{CL}, \mathrm{CH}, \mathrm{SC}$, or $\mathrm{OH}$ under the Unified Soil Classification System, a liquid limit equal to at least 30 with a plasticity of no less than 15, and a maximum permeability of $10^{-7} \mathrm{~cm} / \mathrm{s}$. In addition, the column studies showed that the permeability of these liner composites was not adversely affected by contact with the anticipated tailings leachate. The stability of hydraulic conductivity data for these liner mixes under long-term contact with tailings leachate indicates clay dispersion is not significant. Although these liner mixes do not approach the recommended soil pH of 7 or greater, the neutral nature of the Canonsburg tailings batch extracts and column leaching effluents indicates that liming of these composites could effectively increase the initial liner $\mathrm{pH}$ and that in the long term, the tailings leachate itself should be effective in maintaining a neutral $\mathrm{pH}$ condition.

(ㄱ) Registered trademark of Hungerford and Terry, Inc., Clayton, New Jersey. 
TABLE 3. Characteristics of the Three Canonsburg Liner Mixes

\begin{tabular}{|c|c|c|c|c|c|c|c|c|c|c|c|c|c|c|}
\hline Sample & $\begin{array}{c}\begin{array}{c}\text { Unified } \\
\text { Soil } \\
\text { Classification } \\
\text { Syste }\end{array} \\
\end{array}$ & $\begin{array}{l}\text { Liquid } \\
\text { Limit }\end{array}$ & $\begin{array}{l}\text { Plastic } \\
\text { Limit }\end{array}$ & $\begin{array}{l}\text { Plasticity } \\
\text { Index }\end{array}$ & $\begin{array}{l}\text { Particle } \\
\text { Density. } \\
\text { g/Cus }\end{array}$ & $\begin{array}{c}\text { Clay, } \\
\underline{x}\end{array}$ & $\begin{array}{c}\text { Sand, } \\
\times \\
\end{array}$ & $\begin{array}{c}\text { Silt, } \\
2 \\
\end{array}$ & $\begin{array}{l}\text { plt Soil } \\
\text { Paste, } \\
\text { pH Units }\end{array}$ & $\begin{array}{l}\text { En } 1: 1 \\
\text { Extract, } \\
\text { tinV }\end{array}$ & $\begin{array}{c}\text { Cation } \\
\text { Exchange } \\
\text { Capacity, } \\
\text { meg/100 } 9\end{array}$ & $\begin{array}{c}\text { Calcium } \\
\text { Carbonate } \\
\text { Content, } \\
x \\
\end{array}$ & $\begin{array}{c}\text { Free Iran } \\
\text { 0xide } \\
\text { Content, } \\
\quad \$ \\
\end{array}$ & $\begin{array}{c}\text { Surface } \\
\text { Azea, } \\
\mathbf{D}^{2} / \mathrm{q}\end{array}$ \\
\hline $\begin{array}{l}\text { Unamended } \\
\text { Composite }\end{array}$ & ML & 32 & 26 & 6 & 2.78 & 21 & 23 & 56 & 4.66 & 504 & 16.4 & 0.05 & 0.27 & 56 \\
\hline $\begin{array}{l}\text { Composite Plus } 24 \\
\text { Iron Oxide }\end{array}$ & $\mathrm{CL}$ & 29 & 23 & 6 & 2.78 & 18 & 25 & 57 & 4.66 & 459 & 22.1 & 0.06 & 0.31 & 108 \\
\hline $\begin{array}{l}\text { Camposite Plus } 24 \\
\text { Manganese }\end{array}$ & CL & 28 & 22 & 6 & 2.78 & 20 & 21 & 59 & 4.69 & 479 & 16.4 & 0.06 & 0.43 & 95 \\
\hline
\end{tabular}




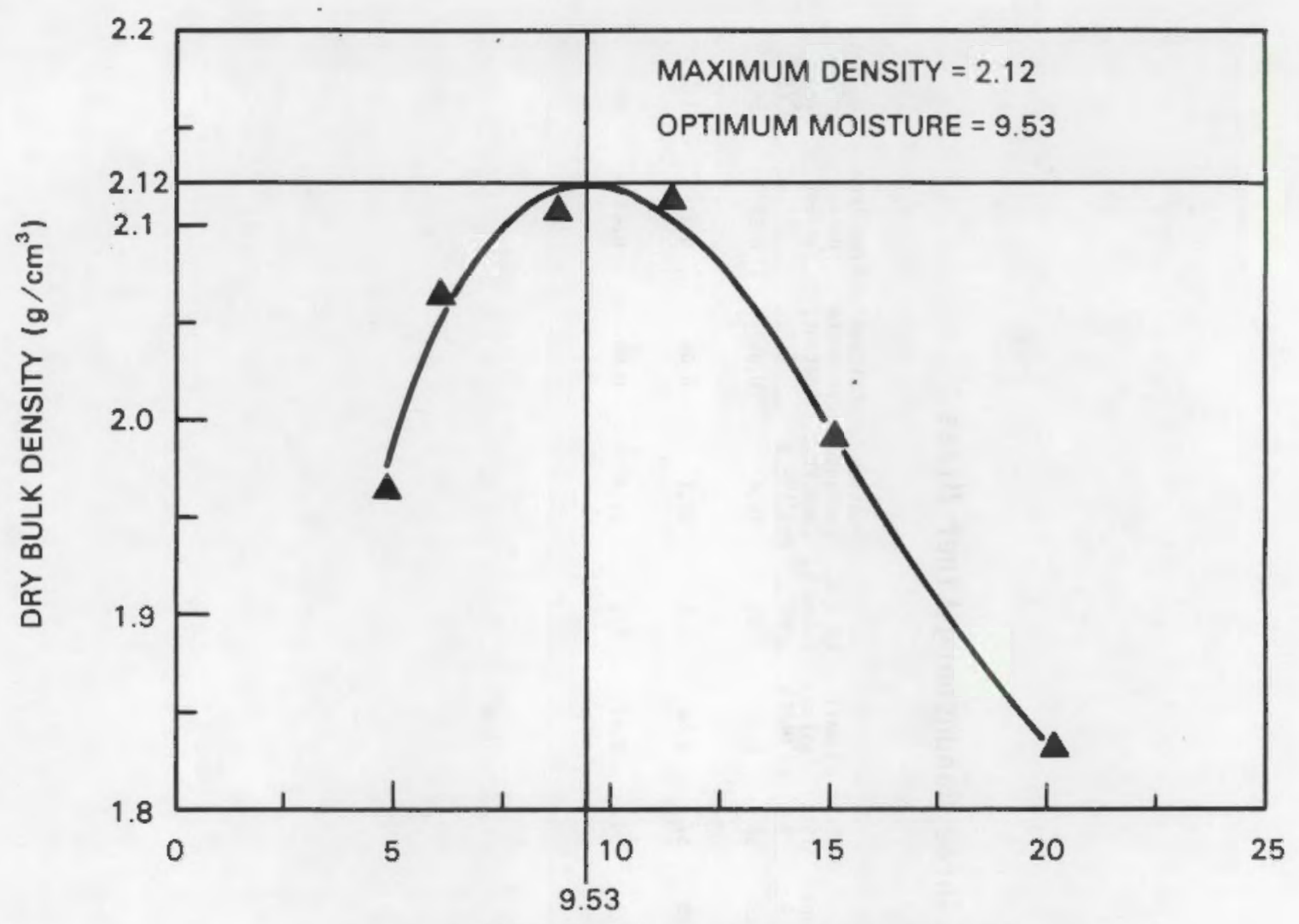

MOISTURE CONTENT ( $\%$ DRY WEIGHT)

FIGURE 4. Moisture Density Relationship for Unamended Composite (ASTM 1557-D, Proctor Density; ASTM 1982)

TABLE 4. Clay Mineral Percentages of Unamended Canonsburg Mix

$\frac{\begin{array}{c}\text { Vermiculite- } \\ \text { Chlorite }\end{array}}{10} \frac{\begin{array}{c}\text { Expanded } \\ \text { Illite }\end{array}}{20} \frac{\begin{array}{c}\text { Illite } \\ \text { (mica) }\end{array}}{50} \quad \frac{\text { Kaolinite }}{20} \quad \frac{\text { Quartz }}{\text { trace }}$

\section{TAILINGS ANALYSIS}

The initial step in the production of a tailings solution for column flow studies involved the chemical characterization of the solid tailings. The technique of $x$-ray fluorescence allows for the accurate determination of elemental concentrations in solid samples and provides base-line levels from 
which mobility predictions can be inferred. Field moisture data and the chemical characteristics of each Canonsburg tailings sample may be found in Table 5 .

The data in Table 5 show the Canonsburg tailings samples to be neutral in $\mathrm{pH}$, saturated with water and to contain moderate levels of organic matter. In addition to the natural organic material provided by the lush vegetation and saturated tailings conditions at the Canonsburg waste site, Marcos, Bush and Freeman (1981) indicate the presence of kerosene, oil, tar, coal, and other synthetic organic compounds. The reactions of these synthetic organic compounds in soil systems have not been fully studied and no conclusions on their effects on contaminant migration can be offered. The role of fulvic acid and other naturally produced organic compounds in trace metal availability has received more attention. The effect of these organic compounds on waste attenuation, through complexation of heavy metals and the reduction of iron and manganese oxides present in the soil liner system, is generally to increase the availability of previously nonmobile constituents (Jenne 1968; Bohn, McNeal and 0'Connor 1979). However, if some of the important organic complexes are also nonmobile in soil environments, contaminant fixation may occur. The minimal data obtained in this study make any predictions of the role of organic compounds at the Canonsburg site impossible without more detailed investigation. The data necessary for such predictions could be obtained using combined gas chromatography and mass spectroscopy.

Although the Canonsburg tailings are at, or near, saturated water content, the presence of the easily leachable macro ions calcium and chloride in the solid tailings suggests leaching of the tailings has been limited. Depending on the water retention (drainage) characteristics of the tailings, physical relocation and encapsulation of the tailings could be hampered by the high water content, especially in samples $4 \mathrm{~A}$ and $5 \mathrm{~A}$, which approached $50 \%$ water content on a dry weight basis and actually exuded water when allowed to stand undisturbed. The trace metals $\mathrm{As}, \mathrm{Co}, \mathrm{Cu}, \mathrm{Ni}$, and $\mathrm{Pb}$ and the radionuclides $210 \mathrm{~Pb},{ }^{238} \mathrm{U},{ }^{230} \mathrm{Th}$, and ${ }^{226} \mathrm{Ra}$ were present in elevated concentrations throughout the tailings samples analyzed, but seemed to be especially concentrated in samples $1 \mathrm{~A}$ and $4 \mathrm{~A}$. 
TABLE 5. Chemical and Radionuclide Concentrations of Solid Canonsburg Tailings

\begin{tabular}{|c|c|c|c|c|c|}
\hline Parameter & Waste $1 \mathrm{~A}$ & Waste $2 \mathrm{~A}$ & Waste $3 \mathrm{~A}$ & Waste $4 \mathrm{~A}$ & Waste $5 \mathrm{~A}$ \\
\hline Field water content $(\mathrm{g} / \mathrm{g})$ & 0.344 & 0.362 & 0.365 & 0.498 & 0.419 \\
\hline Organic matter $(\%)$ & 2.63 & 0.79 & 1.79 & 2.60 & 2.95 \\
\hline $\mathrm{pH}$ saturated paste & 7.53 & 6.78 & 6.12 & 7.01 & 6.28 \\
\hline En $1: 1$ extract (+mV) & 268 & 301 & 346 & 386 & 349 \\
\hline \multicolumn{6}{|l|}{ Macro Ions $(\mu \mathrm{g} / \mathrm{g})^{(a)}$} \\
\hline $\begin{array}{l}\mathrm{Al} \\
\mathrm{Ca} \\
\mathrm{Fe} \\
\mathrm{Mn} \\
\mathrm{Si} \\
\mathrm{Sr} \\
\mathrm{K} \\
\mathrm{S}\left(\text { as } \mathrm{SO}_{4}\right) \\
\mathrm{Cl} \\
\mathrm{P}\end{array}$ & $\begin{array}{r}59,000 \\
14,000 \\
38,000 \\
584 \\
216,000 \\
131 \\
14,000 \\
10,000 \\
1,000 \\
4,000\end{array}$ & $\begin{array}{r}81,000 \\
6,000 \\
76,000 \\
1,392 \\
251,000 \\
88 \\
18,000 \\
28,000 \\
650 \\
3,000\end{array}$ & $\begin{array}{r}59,000 \\
7,000 \\
43,000 \\
922 \\
216,000 \\
106 \\
14,000 \\
4,000 \\
1,000 \\
4,000\end{array}$ & $\begin{array}{r}56,000 \\
12,000 \\
46,000 \\
1,057 \\
201,000 \\
126 \\
12,000 \\
4,000 \\
1,000 \\
4,000\end{array}$ & $\begin{array}{r}71,000 \\
4,000 \\
50,000 \\
724 \\
281,000 \\
70 \\
16,000 \\
1,000 \\
660 \\
2,700\end{array}$ \\
\hline \multicolumn{6}{|l|}{ Trace Metals $(\mu \mathrm{g} / \mathrm{g})^{(a)}$} \\
\hline $\begin{array}{l}\mathrm{As} \\
\mathrm{Co} \\
\mathrm{Cr} \\
\mathrm{Cu} \\
\mathrm{Ni} \\
\mathrm{Pb} \\
\mathrm{Mo} \\
\mathrm{Rb} \\
\mathrm{Se} \\
\mathrm{U} \text { (total by XRF) } \\
\mathrm{V} \\
\mathrm{Zn} \\
\mathrm{Zr}\end{array}$ & $\begin{array}{r}1,055 \\
855 \\
84 \\
666 \\
929 \\
1,111 \\
44 \\
17 \\
2.7 \\
570 \\
442 \\
426 \\
308\end{array}$ & $\begin{array}{r}262 \\
90 \\
97 \\
104 \\
141 \\
120 \\
10 \\
76.9 \\
1.0 \\
150 \\
657 \\
140 \\
271\end{array}$ & $\begin{array}{r}1,670 \\
1,063 \\
30 \\
941 \\
1,771 \\
1,393 \\
15 \\
43 \\
2.0 \\
278 \\
247 \\
150 \\
389\end{array}$ & $\begin{array}{r}2,730 \\
2,640 \\
193 \\
4,050 \\
3,000 \\
2,460 \\
56 \\
7.0 \\
1.0 \\
824 \\
509 \\
269 \\
429\end{array}$ & $\begin{array}{r}203 \\
183 \\
84 \\
153 \\
295 \\
286 \\
9 \\
73.2 \\
0.8 \\
57 \\
106 \\
95 \\
381\end{array}$ \\
\hline \multicolumn{6}{|l|}{ Radionuclides $(p C i / g){ }^{(b)}$} \\
\hline $210_{\mathrm{Pb}}$ & 3,047 & 70 & 536 & 2,412 & 162 \\
\hline $238_{U}$ & 186 & 28 & 47 & 164 & 15 \\
\hline${ }^{230} \mathrm{Th}$ & 4,114 & 157 & 648 & 1,976 & 250 \\
\hline $226_{\mathrm{Ra}}$ & 3,030 & 70 & 604 & 2,634 & 150 \\
\hline
\end{tabular}

(a) Solid samples analyzed using $x$-ray fluorescence (XRF).

(b) Solid samples analyzed using high-resolution gamma counting. 
PRODUCTION AND ANALYSIS OF TAILINGS LEACHATE: BATCH STUDIES

Chemical analyses of the extracts produced from 1:1 tailings-deionized water batch contact studies and the solutions used for leaching columns are given in Table 6 . High-resolution gamma counting of the salts produced by evaporating $0.5 \mathrm{~L}$ of the $1: 1$ extracts showed that concentrations of $210 \mathrm{~Pb}$ and ${ }^{230} \mathrm{Th}$ were below the detection levels of this analytical technique $(50 \mathrm{pCi} / \mathrm{L}$ and $400 \mathrm{pCi} / \mathrm{L}$, respectively). Over a 7-hour counting time, no counts above background were recorded at the energy levels ( $46 \mathrm{keV}$ and $67 \mathrm{keV}$ ) representing $210 \mathrm{pb}$ and $230 \mathrm{Th}$ even when counting the extract evaporates from tailings samples $1 A$ and $4 A$, which are known to contain high concentrations of these radioactive isotopes before extraction. The fact that no counts were recorded at these energy levels indicated that the concentrations of these two radioactive isotopes were also close to zero in the 1:1 tailings extracts. Therefore, no further efforts were made to obtain more precise concentration values for $1: 1$ batch extracts or for column effluent samples.

High-resolution gamma analyses of the tailings extract evaporites for $238_{U}$ and ${ }^{226} \mathrm{Ra}$ also provided data indicating these radioactive isotopes were present at levels below detection limits $(50 \mathrm{pCi} / \mathrm{L})$ for tailings samples $2 \mathrm{~A}, 3 \mathrm{~A}$, and $5 \mathrm{~A}$. However, where the counting data for ${ }^{210} \mathrm{~Pb}$ and ${ }^{230} \mathrm{Th}$ indicated concentrations approaching zero, counting of the $1: 1$ extracts showed a nonquantifiable peak at the energy levels corresponding to $238_{U}$ and $226_{R a}$. Although the peak areas recorded were statistically too close to background levels to allow reporting of any values greater than detection levels, the presence of peaks from uranium and radium prompted the investigation of their concentrations using more sensitive techniques. Counting the $1: 1$ extract evaporites of tail- . ings samples $1 \mathrm{~A}$ and $4 \mathrm{~A}$ produced gamma spectroscopy results that indicated high levels of both uranium-238 and radium-226. Measured levels of uranium-238 and radium-226 were 17,300 and $14,900 \mathrm{pCi} / \mathrm{L}$ for tailings extract $1 \mathrm{~A}$ and 15,500 and $9,000 \mathrm{pCi} / \mathrm{L}$ for tailings extract $4 \mathrm{~A}$, respectively. As discussed in the following sections, these values are anomalously high and cannot be verified using more accurate measurement techniques such as laser fluorescence and alpha 
scintillation counting, which place uranium and radium concentration at substantially lower concentrations. After these analyses we discovered that electronic malfunctions in the ND660 Nuclear Analyzer probably caused the high values. Hence, we do not use these values in further discussions of results.

The data in Table 6 confirm that tailings samples $1 \mathrm{~A}$ and $4 \mathrm{~A}$ represent the greatest potential leaching hazard at the Canonsburg site. The 1:1 water extracts from these two samples show elevated concentrations of cations, anions, trace metals, and radionuclides as compared to the 1:1 water extracts from the remaining three tailings samples. Although the differences in constituent concentrations between the 1:1 extracts were not as great as they were in the solid phase (see Table 5), these results led us to produce two separate tailings solutions for use in the following column attenuation studies. The first solution (tailings solution I), which would be most representative of a tailings leachate found at the Canonsburg site, was prepared from an equal volume mixture of the extracts from all five solid tailings samples. The second solution (tailings solution II) was prepared using equal volumes of extracts from solid tailings samples No. $1 \mathrm{~A}$ and No. $4 \mathrm{~A}$ only. Tailings solution II was chosen as a worst-case simulation and because it was likely to have sufficient trace metal and radionuclide concentrations to be measurable in column effluents. Large volumes of tailings solution (10 L) were produced using the same methods used to prepare the 1:1 tailings extracts. The chemical characterization data for solution I and solution II, are also given in Table 6.

The neutral pH of the two tailings solutions gave rise to initial concerns about the stability of their constituent concentrations. The $\mathrm{pH}$ and Eh of aliquots from the 1:1 tailings extraction studies were monitored over several days and found to remain constant. In addition, constituent concentrations of the influent tailings solutions were measured periodically during the course of the column studies and found to be stable. The neutral pH conditions in the Canonsburg solid tailings resulted not only in 1:1 water extracts of neutral $\mathrm{pH}$, but also in the fixation of most contaminants in the solid phase. The chemical analysis data in Table 5 for the solid tailings show elevated levels of several toxic metals and radionuclides. By comparison, chemical analysis of 
TABLE 6. Characteristics of 1:1 Tailings Extracts and Tailings Solution I and II

\begin{tabular}{|c|c|c|c|c|c|c|c|}
\hline Parameter & Waste $1 \mathrm{~A}$ & Waste 2A & Waste 3A & Waste $4 \mathrm{~A}$ & Waste $5 \mathrm{~A}$ & $\begin{array}{l}\text { Tajlings } \\
\text { Solutjon } \\
\text { I }\end{array}$ & $\begin{array}{l}\text { Tailings } \\
\text { Solution } \\
\text { II }(\mathrm{B}) \\
\end{array}$ \\
\hline $\mathrm{pH}$ (pH units) & 8.47 & 8.23 & 8.25 & 8.35 & 8.28 & 7.98 & 7.75 \\
\hline Eh $(+m V)$ & 268 & 301 & 346 & 386 & 349 & 282 & 304 \\
\hline $\begin{array}{l}\text { Alkalinity } \\
\left(\mathrm{mg} \mathrm{CO} \mathrm{CO}_{3} / \mathrm{L}\right)\end{array}$ & 175.5 & 50.9 & 63.6 & 114.5 & 17.8 & 256.9 & 165.4 \\
\hline \multicolumn{8}{|c|}{ Macro ions (ppm) } \\
\hline $\begin{array}{l}\mathrm{Al} \\
\mathrm{Ba} \\
\mathrm{Ca} \\
\mathrm{Fe} \\
\mathrm{K} \\
\mathrm{Li} \\
\mathrm{Mg} \\
\mathrm{Na} \\
\mathrm{P} \\
\mathrm{S} \\
\mathrm{Si} \\
\mathrm{Sr} \\
\mathrm{Cl} \\
\mathrm{F} \\
\mathrm{NO}_{3} \\
\mathrm{SO}_{4}\end{array}$ & $\begin{array}{r}1.52 \\
0.11 \\
685 \\
0.45 \\
34.4 \\
<0.01 \\
41.8 \\
2,061 \\
1.99 \\
1,879 \\
12.3 \\
1.6 \\
35 \\
6.6 \\
5 \\
5,000\end{array}$ & $\begin{array}{r}<0.03 \\
0.07 \\
660 \\
0.16 \\
15.2 \\
<0.01 \\
70.1 \\
131 \\
0.82 \\
727.5 \\
9.2 \\
1.6 \\
35 \\
<1.0 \\
5 \\
1,630\end{array}$ & $\begin{array}{r}<0.03 \\
0.03 \\
458 \\
0.17 \\
15.0 \\
<0.01 \\
85.8 \\
1,001 \\
0.82 \\
1,267 \\
10.4 \\
1.5 \\
43 \\
3.6 \\
5 \\
3,300\end{array}$ & $\begin{array}{r}0.55 \\
0.07 \\
731 \\
0.11 \\
17.7 \\
<0.01 \\
119 \\
860 \\
1.85 \\
1,191 \\
18.4 \\
1.4 \\
73 \\
4.5 \\
5 \\
3,470\end{array}$ & $\begin{array}{r}<0.03 \\
0.14 \\
103 \\
0.42 \\
7.5 \\
<0.01 \\
20.7 \\
113 \\
0.85 \\
188.6 \\
8.2 \\
0.37 \\
76 \\
<1.0 \\
5 \\
350\end{array}$ & $\begin{array}{r}<0.03 \\
0.01 \\
171 \\
0.01 \\
9.78 \\
<0.01 \\
33.5 \\
407 \\
<0.10 \\
418 \\
5.8 \\
0.58 \\
31 \\
2.4 \\
1.7 \\
1,500\end{array}$ & $\begin{array}{r}0.43 \\
0.08 \\
442 \\
0.71 \\
29.9 \\
0.02 \\
61.9 \\
1,015 \\
0.22 \\
1,290 \\
10.3 \\
1.03 \\
31 \\
4.6 \\
14 \\
3,200\end{array}$ \\
\hline \multicolumn{8}{|c|}{ Trace Metals (ppm) } \\
\hline $\begin{array}{l}\mathrm{As} \\
\mathrm{Cd} \\
\mathrm{Ce} \\
\mathrm{Co} \\
\mathrm{Cr} \\
\mathrm{Cu} \\
\mathrm{Mo} \\
\mathrm{Ni} \\
\mathrm{Pb} \\
\mathrm{Se} \\
\mathrm{V} \\
\mathrm{Zn} \\
\mathrm{Zr}\end{array}$ & $\begin{array}{r}0.04 \\
0.01 \\
<0.06 \\
0.44 \\
<0.01 \\
0.05 \\
5.93 \\
0.37 \\
<0.02 \\
<0.02 \\
0.09 \\
0.51 \\
<0.01\end{array}$ & $\begin{array}{r}<0.02 \\
<0.01 \\
<0.06 \\
0.03 \\
<0.01 \\
0.05 \\
0.05 \\
<0.06 \\
<0.02 \\
<0.02 \\
0.02 \\
0.03 \\
<0.01\end{array}$ & $\begin{array}{r}0.40 \\
0.02 \\
<0.06 \\
0.48 \\
<0.01 \\
0.16 \\
0.04 \\
0.72 \\
<0.02 \\
<0.02 \\
<0.05 \\
0.21 \\
<0.01\end{array}$ & $\begin{array}{r}1.01 \\
<0.01 \\
<0.06 \\
2.00 \\
<0.01 \\
1.30 \\
3.88 \\
3.45 \\
<0.02 \\
<0.02 \\
0.16 \\
0.06 \\
<0.01\end{array}$ & $\begin{array}{r}0.02 \\
<0.01 \\
<0.06 \\
0.11 \\
<0.01 \\
0.06 \\
0.01 \\
0.06 \\
<0.02 \\
<0.02 \\
<0.05 \\
0.05 \\
<0.01\end{array}$ & $\begin{array}{r}0.13 \\
<0.01 \\
0.06 \\
0.13 \\
<0.01 \\
0.06 \\
0.17 \\
0.19 \\
<0.02 \\
<0.02 \\
0.05 \\
0.02 \\
<0.01\end{array}$ & $\begin{array}{r}1.30 \\
<0.01 \\
<0.03 \\
0.47 \\
<0.01 \\
0.16 \\
3.42 \\
0.74 \\
<0.02 \\
<0.02 \\
<0.14 \\
0.08 \\
0.02\end{array}$ \\
\hline
\end{tabular}

Radionuclides

$\begin{array}{lrrrrrrr}U(\operatorname{total})(\mathrm{ppm}) & \text { N.D. (c) } & \text { N.D. } & \text { N.D. } & \text { N.D. } & \text { N.D. } & 2.9 & 16.5 \\ \operatorname{Ra}-226(\mathrm{pC} i / L) & \text { N.D. } & \text { N.D. } & \text { N.D. } & \text { N.D. } & \text { N.D. } & 659 & 1,790 \\ P b-210(\mathrm{pCi} / \mathrm{L}) & <50 & <50 & <50 & <50 & <50 & \text { N.D. } & \text { N.D. } \\ T h-230(\mathrm{pC} i / L) & <400 & <400 & <400 & <400 & <400 & \text { N.D. } & \text { N.D. }\end{array}$

(a) Solution I - Combination of equal parts of waste leachates $1 \mathrm{~A}, 2 \mathrm{~A}, 3 \mathrm{~A}, 4 \mathrm{~A}$, and $5 A$.

(b) Solution II - Combination of equal parts of waste leachates $1 \mathrm{~A}$ and $4 \mathrm{~A}$.

(c) N.D. = Not Determined 
the 1:1 tailings extracts (Table 6 ) indicates that, with the exception of $\mathrm{SO}_{4}$ and ${ }^{226} \mathrm{Ra}$, the concentrations of all contaminants measured are at least ten, and in many cases, one thousand times lower than those present in the solid tailings. Even the most heavily contaminated 1:1 tailings extracts show only the trace metals ( $\mathrm{As}, \mathrm{Cd}, \mathrm{Cu}, \mathrm{Fe}, \mathrm{Mo}, \mathrm{Se}$ ) and the anions $\left(\mathrm{NO}_{3}\right.$ and $\left.\mathrm{SO}_{4}\right)$ to be present above the maximum concentration levels for drinking water as set by the EPA $(1979,1980)$ shown in Table 7 . In addition, the radiological data in Table 6 show radium-226 concentrations in the final tailings solution mixtures to be well over the set limits.

These data suggest an explanation for the field results reported by Marcos, Bush and Freeman (1981). They stated that the chemical analysis of the water-extractable components from samples taken above and below the tailingssoil interface at the Canonsburg site showed an abrupt decrease in contaminants at the interface. The fact that the contaminants were immobilized in the first few centimeters of soil below the tailings is possibly due as much to the low contaminant concentrations in the downward-migrating tailings leachate as to the attenuation characteristics of the sediments underlying the tailings. Contaminant Attenuation Results

These column studies were designed to examine the interactions of a waste leachate with a soil liner and to quantify the contaminant attenuation effects of the liner medium on the waste stream. At the same time, these column flow studies also represent liner leaching columns, where the waste solution may remove constituents from the liner matrix. Because of the low concentrations of several constituents in the influent tailings leachates, even slight removal of constituents from the liner material could bias the column study results. Rather than run separate column leaching studies using each liner material and a more appropriate leaching solution, 1:1 batch extraction tests were conducted using the unamended and amended liner mixes and deionized water.

The data from these batch extraction tests for each of the three liner mixes are given in Appendix $A$; the $1: 1$ extraction results for the unamended composite are presented in Table 8.

The effluent data for the six attenuation columns (1iner mixes contacted with tailings leachate) and the two leaching columns are presented in 
TABLE 7. Maximum Concentration Levels for Drinking Water (ppm) (a)

\begin{tabular}{|c|c|}
\hline $\mathrm{pH}$ (units) & $6.5+8.5^{(b)}$ \\
\hline As & $0.05(c)$ \\
\hline $\mathrm{Ba}$ & $1.0(c)$ \\
\hline $\mathrm{Cd}$ & 0.01 (c) \\
\hline $\mathrm{Cr}$ & $0.05(c)$ \\
\hline $\mathrm{Cu}$ & $1.0^{(b)}$ \\
\hline $\mathrm{Fe}$ & $0.3^{(b)}$ \\
\hline$M n$ & $0.05^{(c)}$ \\
\hline Mo & 0.05 \\
\hline $\mathrm{Pb}$ & $0.05(c)$ \\
\hline Se & $0.01^{(c)}$ \\
\hline $\mathrm{Zn}$ & $5.0^{(b)}$ \\
\hline$F$ & $1.4+2.4^{(c)}$ \\
\hline $\mathrm{NO}_{3}-\mathrm{N}$ & $10(c)$ \\
\hline & $250^{(b)}$ \\
\hline${ }^{210} \mathrm{~Pb}(\mathrm{pCi} / \mathrm{L})$ & $100^{(d)}$ \\
\hline $238 \mathrm{v}(\mathrm{pC} i / L)$ & $40,000(d)$ \\
\hline${ }^{230} \mathrm{Th}(\mathrm{pC} i / L)$ & $2,000(d)$ \\
\hline${ }^{226} \mathrm{Ra}(\mathrm{pC} i / L)$ & $30^{(d)}$ \\
\hline
\end{tabular}

(a) Drinking Water Standards set by U.S. Public Health Service - U.S. EPA

(b) Secondary Drinking Water Standards (EPA 1979)

(c) Primary Drinking Water Standards (EPA 1980)

(d) Maximum Permissible Concentrations from an unrestricted area 10 CFR 20 Appendix B (NRC 1979).

Appendix $B$. The results covered in this section include the data from the two columns containing unamended composite, Column No. 1 contacted with solution II, Column No. 2 contacted with solution I, and the two leaching columns.

The relationship of column effluent $\mathrm{pH}$ to pore volume of tailings leachate passed through the unamended liner (Columns No. 1 and No. 2) is presented in 
TABLE 8. Chemical Analysis of 1:1 Water Extract from the Unamended Borrow Pit Liner Mix $(\mathrm{ppm})(\mathrm{a})$

\begin{tabular}{|c|c|c|c|c|c|}
\hline \multicolumn{2}{|c|}{ Constituent } & \multicolumn{2}{|c|}{ Constituent } & \multicolumn{2}{|c|}{ Constituent } \\
\hline Al & 0.30 & $\mathrm{Na}$ & 19.3 & $\mathrm{SO}_{4}$ & 450 \\
\hline As & 0.01 & $P$ & 0.13 & $\mathrm{Cr}$ & 0.02 \\
\hline $\mathrm{Ba}$ & 0.03 & $\mathrm{~s}$ & 170.0 & Mo & 0.01 \\
\hline $\mathrm{Ca}$ & 87.6 & Si & 23.0 & $\mathrm{Ni}$ & 0.11 \\
\hline $\mathrm{Fe}$ & 0.02 & $\mathrm{Sr}$ & 0.33 & $\mathrm{Se}$ & $<0.01$ \\
\hline $\mathrm{K}$ & 13.3 & $\mathrm{Cl}$ & 4.1 & $v$ & 0.01 \\
\hline Li & 0.06 & $\mathrm{~F}$ & $<1.5$ & $\mathrm{Zn}$ & 0.24 \\
\hline Mg & 47.5 & $\mathrm{NO}_{3}$ & 7.5 & $\mathrm{Zr}$ & 0.01 \\
\hline
\end{tabular}
(a) $\mathrm{pH}=4.70$
$E \mathrm{E}=504 \mathrm{mV}$
$E C=0.83 \mu$ mhos

Figure 5. Also included in Figure 5 are the influent $\mathrm{pH}$ values of the respective tailings leachates. As the neutral tailings solutions contacted the the liner material, the $\mathrm{pH}$ of the column effluents first dropped slightly, then began to increase. For Column No. 2 this increase in effluent pH continued slowly until the hydronium ions available in the liner material were exhausted, at which point the effluent $\mathrm{pH}$ rapidly increased toward the $\mathrm{pH}$ of the influent waste solution. The start of this steep pH increase was defined as the $\mathrm{pH}$-front breakthrough. The pH data in Figure 5 point to the problems of obtaining reproducible results from even nearly identical columns. Column 2 shows a pH-front breakthrough at $\mathrm{pH} 5.5$ after just 1.25 pore volumes of tailings solution had passed through the column, while Column No. 1 failed to reach this breakthrough point even after 3.0 pore volumes of tailings solution had been percolated through the cell. Review of the $\mathrm{pH}$ versus pore volumes data presented in Appendix $A$ for the remaining four attenuation columns indicate that the pH curve presented for Column No. 1 is more typical of the interactions of Canonsburg tailings leachate with the local borrow pit liner materials. The measured effluent $\mathrm{pH}$ after contact with 3.0 pore volumes of 


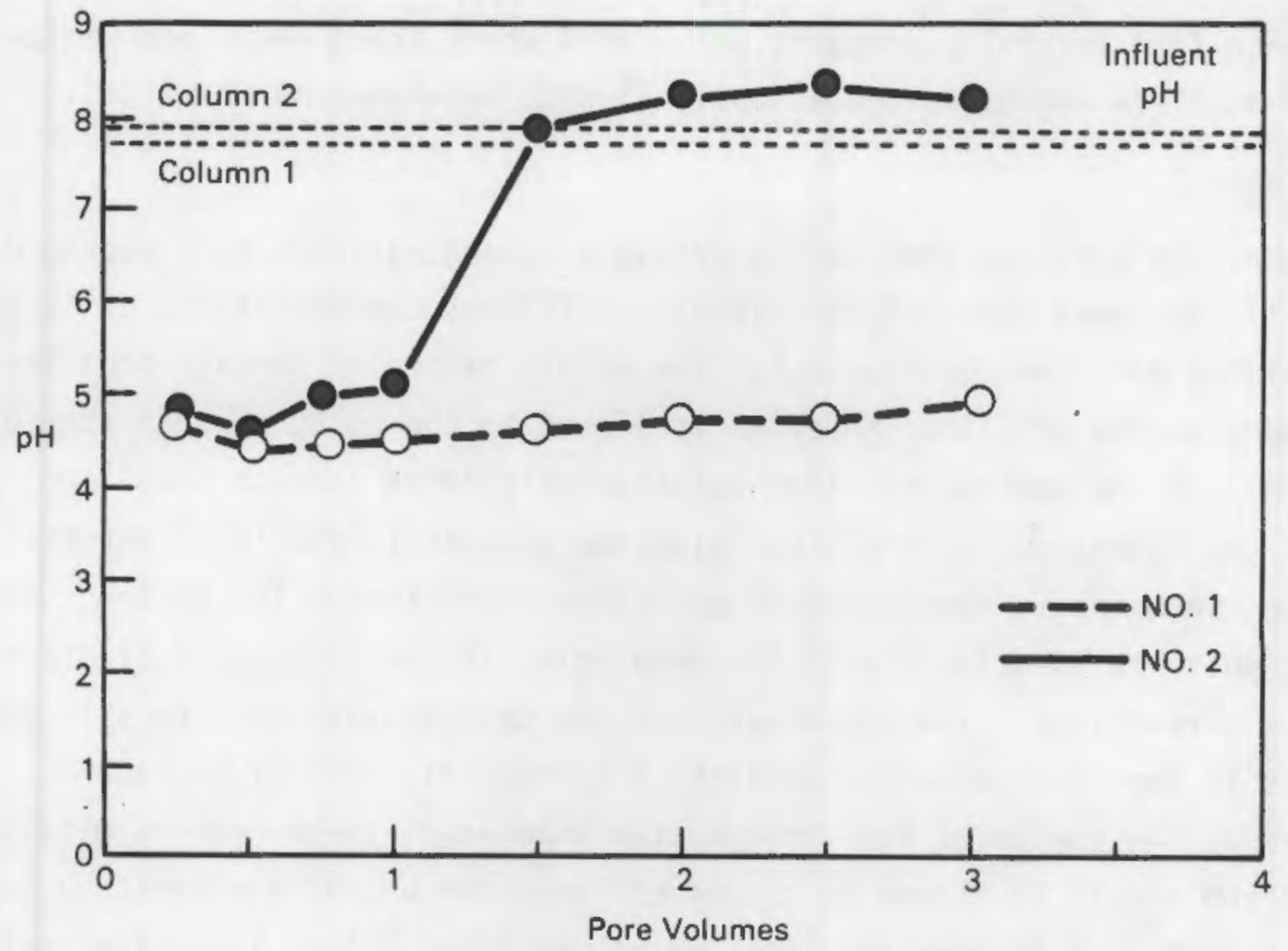

FIGURE 5. Effluent pH Versus Pore Volumes for Attenuation Columns No. 1 and No. 2

tailings solution show pH values of 5.0,5.0 4.8, and 5.3 for Column Nos. 3, 4, 5 and 6 , respectively, with no signs of $\mathrm{pH}-$ front breakthrough for any of these columns before 3.0 pore volumes.

Although there was a difference in the time of $\mathrm{pH}$ breakthrough for Columns No. 1 and No. 2, a trend is evident: increasing effluent pH with continued contact of fresh tailings solution. In time, the effluent $\mathrm{pH}$ values from both columns will approach the $\mathrm{pH}$ values of the tailing leachate solutions. This process may be accelerated by liming of the liner composite before placement, but because the nature of the tailings solutions is neutral, the positive contaminant attenuation properties attributed to soil liming may not be dramatic. Neutralization reactions have apparently already reduced contaminants in the solid tailings (we assume the tailings were originally acidic). Elevating the $\mathrm{pH}$ conditions of the liner by liming will keep solution 
conditions from initially dropping below pH 4 where trace metal and radionuclide mobility increases dramatically (Serne, Peterson and Gee 1983).

\section{Macro Ions}

Macro ion analyses show column effluent concentrations of $\mathrm{Al}$ and $\mathrm{Mg} \mathrm{dra}-$ matically increased over influent levels. Effluent concentrations of $A l$ versus pore volumes are shown in Figure 6 . The acidic nature of seepage from the Canonsburg borrow pit liner material is linked to the solution chemistry of aluminum. As the neutral tailings solution percolates through the liner system, the hydrolysis of trivalent aluminum present in the liner material increases to maintain the system $\mathrm{pH}$ at acidic conditions. The pH-front breakthrough point is associated with the completion of the successive aluminum hydrolysis reactions. The interlayers of the chlorite-vermiculite silicate minerals in the liner material consist of hydroxy-Al, hydroxy-Fe, and hydroxy-Mg. As the $\mathrm{pH}$ of the liner system increases, these hydroxy metals are removed and result in $\mathrm{Al}$ and $\mathrm{Mg}$ column effluent concentrations enriched beyond levels expected if we consider leaching of the liner material and the influent levels of the tailings solution. The data in Tables B.1 to B.6 of Appendix B show that after 1 to 2 pore volumes of tailings leachate have contacted the liner materials, the levels of $\mathrm{Fe}$ in the attenuation column effluents begin to increase. This increase in effluent concentrations coincides with a decrease in effluent $\mathrm{Al}$ and $\mathrm{Mg}$ concentrations. These results were expected because removal of iron from chlorite-vermiculite minerals usually follows that of $A 1$ and $\mathrm{Mg}$ (Bohn, McNeal and O'Connor 1979).

Calcium was present in high concentrations in the tailings solution, perhaps as a result of some past neutralizing process applied to the solid tailings. The slight reduction of $\mathrm{Ca}$ in the liner column effluents probably resulted from ion exchange onto the soil and clay interlayers within the liner material.

Sodium is easily leached because it is unable to compete for ion exchange sites in the presence of trivalent and divalent metal ions. As expected, sodium movement was unrestricted through the soil column, reaching influent concentration levels rapidly and remaining there throughout the duration of the experiment. 


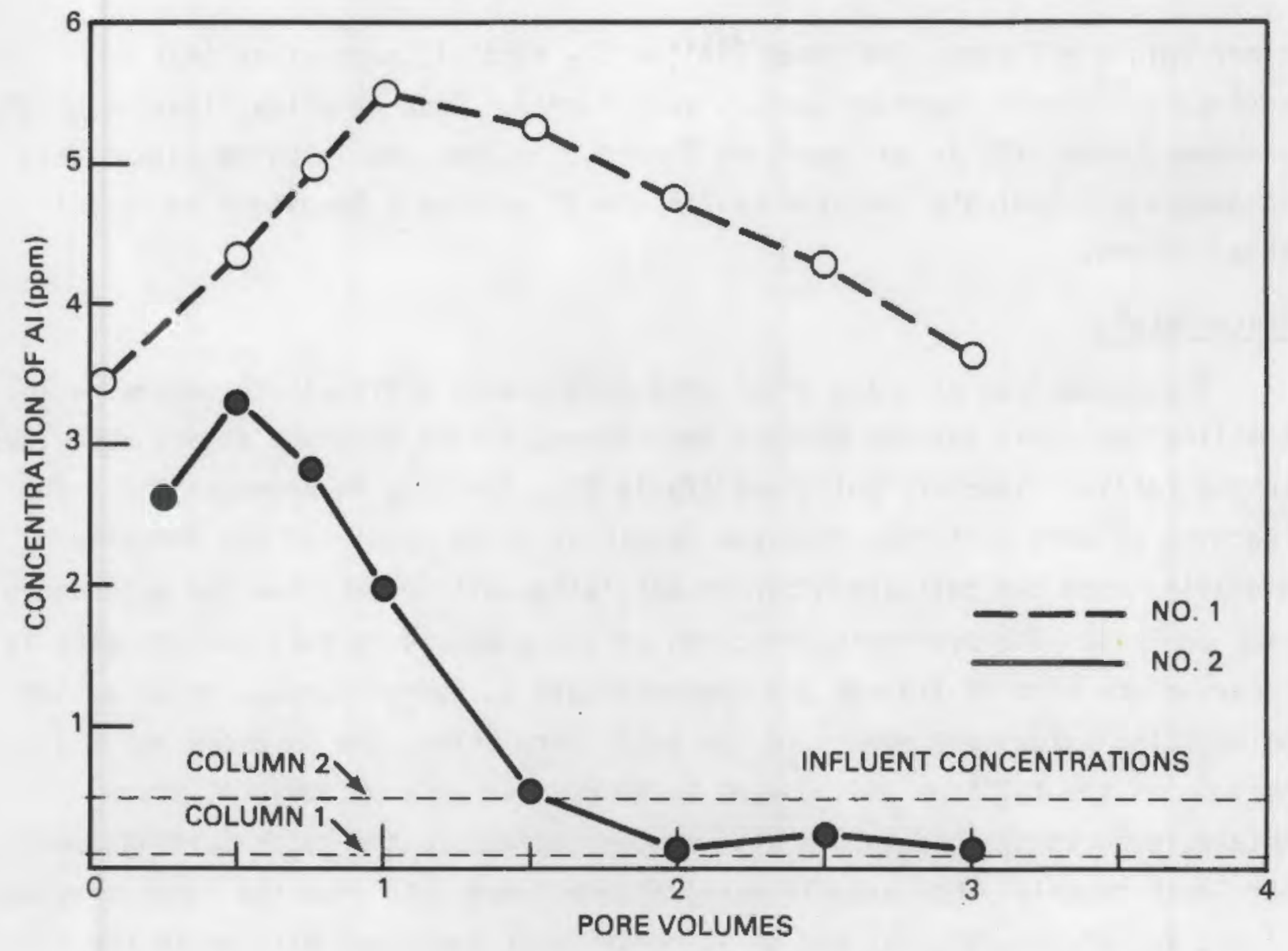

FIGURE 6. Effluent Concentrations of Aluminum Versus Pore Volumes for Attenuation Columns No. 1 and No. 2

The anion $\left(\mathrm{F}, \mathrm{Cl}, \mathrm{NO}_{3}\right.$, and $\left.\mathrm{SO}_{4}\right)$ data show very limited attenuation of each species at 0.25 pore volume for both attenuation Columns No. 1 and No. 2 . With the exception of $\mathrm{NO}_{3}$, the effluent concentration of the anions either reached or slightly exceeded influent concentrations after 0.5 pore volume. The fact that effluent concentrations exceeded those of the influent can be explained by the data in Table 8, which indicate that the unamended liner material was also a source of each of these anions. Nitrate concentrations showed a marked reduction at 1.0 and 2.0 pore volumes for Columns No. 1 and No. 2, respectively, and coincided with a rise in effluent $\mathrm{pH}$ to near 5.0. Nitrate can be expected to move through the attenuation columns at virtually the speed of the influent solution, and be unhindered and chemically unchanged by contact with the liner material. One possible explanation for nitrate fixation would be $i$ ts uptake and reduction by soil microbes to $\mathrm{NH}_{3}$. Sulfate concentrations in the 
liner column effluents indicated limited $\mathrm{SO}_{4}$ removal, suggesting that no secondary minerals, such as gypsum, were formed. Lack of anion fixation by the unamended composite is an important finding, because the leaching column data in Appendix $B$ indicate that the tailings will provide a long-term source of these anions.

Trace Metals

The mechanisms of trace metal attenuation were difficult to determine in the liner material columns because the concentrations of trace metals were low in the tailings leachate solutions (Table 6). The data in Appendix $B$ for the leaching columns confirmed that the levels of trace metals in the leachate migrating from the tailings after encapsulation will remain low for extended time periods. The overriding reaction of trace metals in soil environments is to associate with $\mathrm{OH}$ ligands and coprecipitate as hydroxyoxides, or to adsorb on existing oxides and remain in the solid form unless the pH drops below 4. As long as the tailings environment is maintained at a $\mathrm{pH}$ above 4 , trace metals, even though present in high concentrations in the solid tailings, will not leach readily. For example $x$-ray fluorescence data show the concentrations of $\mathrm{As}, \mathrm{Co}, \mathrm{Cr}, \mathrm{Cu}, \mathrm{Mn}, \mathrm{Pb}$, and $\mathrm{Zn}$ at hundreds of parts per million in the solid tailings, while 1:1 tailings extracts and tailings column leaching effluents show concentrations of many of these transition metals nearing analytical detection levels $(\sim<0.01 \mathrm{ppm})$.

Effluents from the attenuation columns showed very low levels of trace metals. With the exception of $\mathrm{Zn}$, trace metals were present in concentrations below MCLs (Table 7) for all column effluents analyzed. The attenuation column results for $\mathrm{Zn}$ and other trace metals indicated that as the ph conditions of the liner material increased above 4.6 to 4.7 , trace metal effluent concentrations decreased as cation exchange, surface adsorption, precipitation, and perhaps fixation by organic matter became more effective. Below these ph levels, trace metals may remain in solution. The original trace metal concentrations were low in the tailings leachate solutions because of their neutral pH values and do not represent a significant hazard after passing through the liner and emerging at a pH of about 4.5 . 
Uranium

The effluent concentrations of uranium tended to be very low for both unamended columns as the first fractions of a pore volume were collected. These values then increased until 2.0 pore volumes had been collected. After 2.0 pore volumes, concentration levels of uranium fell to below detection limits for Column No. 1, which had the highest flux of uranium (solution II) pass through it. Although the effluent concentrations of uranium were higher for Column No. 2, which had a lower flux of uranium (solution I) pass through it, the levels were still below MCLs. Uranium mobility is controlled to a large extent by its pH-dependent solubility, although adsorption and other fixation mechanisms may attribute to attenuation (Serne, Peterson and Gee 1983). Regardless of the attenuation mechanisms, the data in Appendix $B$ show that once column effluents had reached $\mathrm{pH} 5.0$, only effluents from Column No. 2 possessed uranium concentrations above $0.03 \mathrm{ppm}$. The concentration of uranium versus pore volumes for Columns No. 1 and No. 2 are given in Figures 7 and 8 , respectively. In addition, the infiuent concentrations of uranium are shown. Uranium concentrations in the two influent tailings solutions probably resulted from the formation of soluble carbonate complexes during leaching of the solid tailings because the alkalinity values were quite high in both tailings solutions 1 and II (see Table 6). The data presented in Tables B.7 and B.8 (Appendix B) show that uranium concentrations present in the effluents from the tailings leaching columns decrease with increased leaching. Thus, as the encapsulated tailings are leached over time the potential uranium hazard will decrease.

$\underline{\text { Radium }}$

The results of radium-226 analysis for the unamended liner flow columns No. 1 and No. 2 and the two solid tailings leaching columns are given in Table 9. Influent tailings solutions $I$ and $I 1$ contained 659 and 1,790 pCi/L of radium-226, respectively. The results of radium-226 analysis for the remaining two amended liner flow columns contacted with tailings solution II are given in Appendix B. Radium concentrations are not presented for the two amended soil columns contacted with tailings solution I in Appendix B, nor for the fractional pore volumes of attenuation columns No. 1, 2, 3, and 5 due to the high 


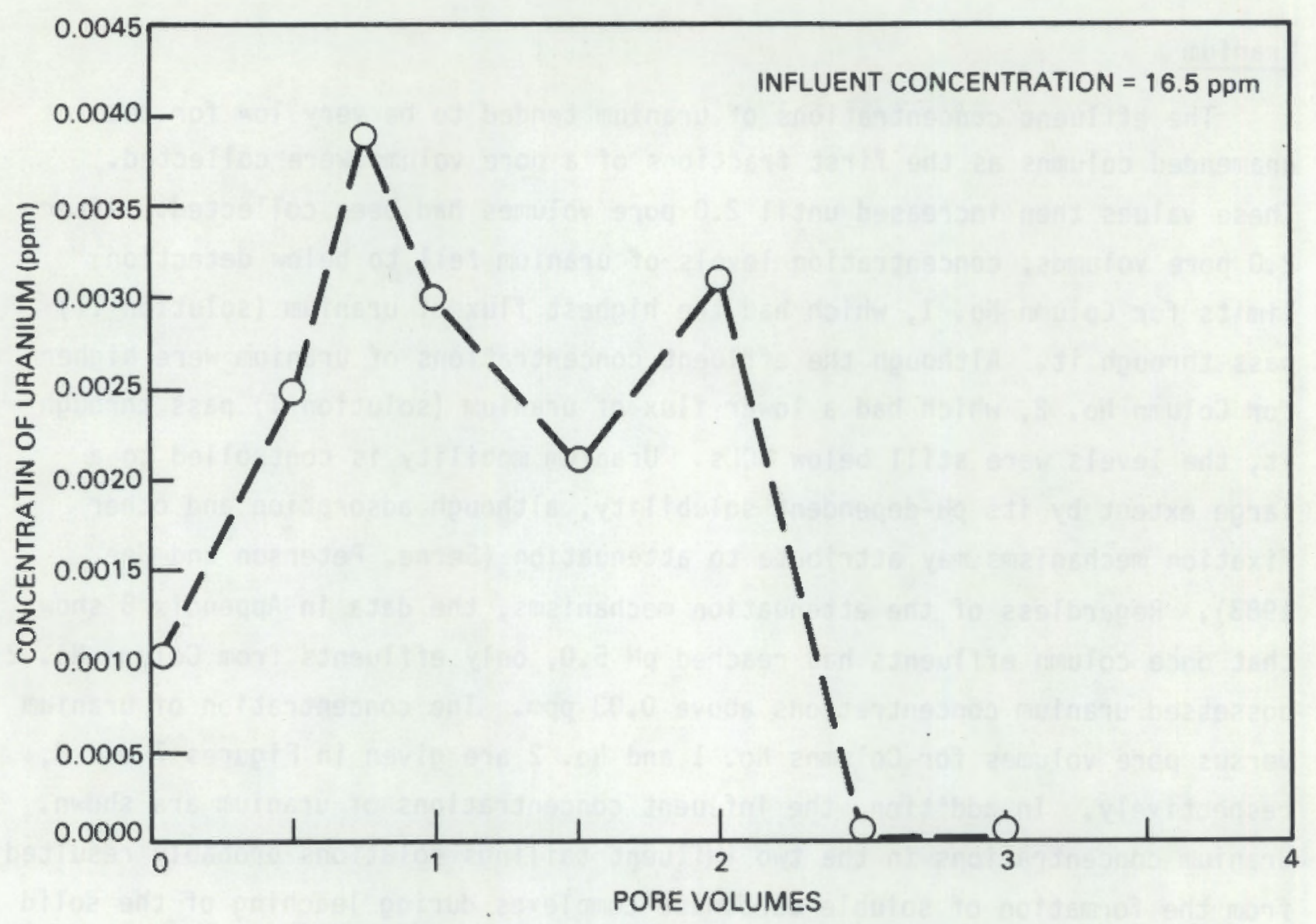

FIGURE 7. Concentration of Uranium Versus Pore Volumes for Attenuation Column No. 1

cost of radium analyses. Effluent radium concentrations in leaching column No. 2 after 1.5 pore volumes are not available because these samples had not been collected when all samples were submitted for radium analyses. The data presented in Table 9 for the unamended soil columns No. 1 and No. 2 are completely opposite from our expectations considering the radium-226 concentrations of the two influent solutions. These data fail to give a clear picture of radium attenuation by the unamended liner composite. After reviewing the data in Table 9, the unamended soil column No. 2 was dismantled and examined for signs of fracture or wall flow and found to be perfectly intact. In addition, the permeability data indicate that such fracture flow or shortcircuiting along the walls probably did not occur at any point during the 


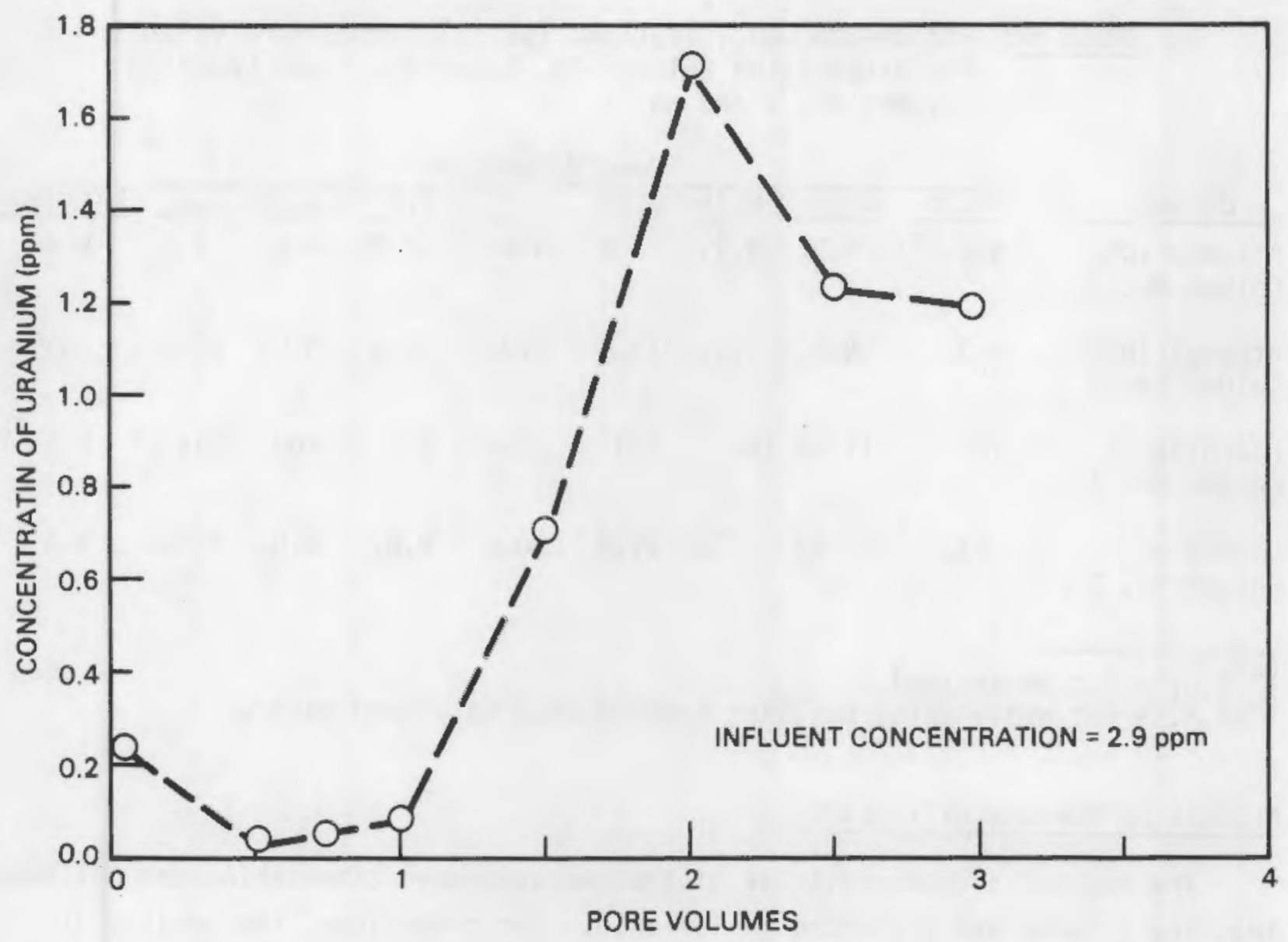

FIGURE 8. Concentration of Uranium Versus Pore Volumes for Attenuation Column No. 2

study. The data in Tables B.7 and B.8 for the leaching of the Canonsburg tailings show that prolonged leaching produced increased radium solubility, and that increased radium solubility coincides with decreased effluent concentrations of sulfate. Similar results have been reported by Levins, Ryan and Strong (1978). They suggest that the presence of sulfate can supress the dissolution of radium because of the insolubility of radium sulfate. Their work suggests that continued washing of tailings with deionized water dissolves more radium than acid leaching, with sulfate concentrations in the wash solution setting the upper limit of radium solubility. These results suggest that radium will be a long-term hazard if an efficient attenuation method is not incorporated into the disposal scheme, and that this hazard may increase with time if moisture is allowed to pass through the encapsulated tailings. 
TABLE 9. Radium-226 Concentrations ( $\mathrm{pCi} / \mathrm{L}$ ) Versus Pore Volumes for Attenuation Columns No. 1 and No. 2 and Leaching Columns No. 1 and No. 2

\begin{tabular}{|c|c|c|c|c|c|c|c|c|c|}
\hline \multirow[b]{2}{*}{ Column } & \multicolumn{8}{|c|}{ Pore Volumes } & \multirow[b]{2}{*}{ Influent } \\
\hline & 0.25 & 0.50 & 0.75 & 1.00 & 1.50 & 2.0 & 2.50 & 3.0 & \\
\hline $\begin{array}{l}\text { Attenuation } \\
\text { Column No. } 1\end{array}$ & N.D. (a) & N.D. & N.D. & 2.9 & N.D. & 2.0 & N.D. & 1.7 & 1790 \\
\hline $\begin{array}{l}\text { Attenuation } \\
\text { Column No. } 2\end{array}$ & N.D. & N.D. & N.D. & 13.8 & N.D. & 42.8 & N.D. & 62.3 & 659 \\
\hline $\begin{array}{l}\text { Leaching } \\
\text { Column No. } 1\end{array}$ & 129 & 114.6 & 103 & 133 & 224 & 285 & 200 & 214 & N.A. (b) \\
\hline $\begin{array}{l}\text { Leaching } \\
\text { Column No. } 2\end{array}$ & 51 & 50 & 70 & 59.4 & 80.6 & N.D. & N.D. & N.D. & N.A. \\
\hline
\end{tabular}

\section{RESULTS OF PERMEABILITY TESTS}

The hydraulic conductivities of the two unamended attenuation and tailings leaching columns are presented in Table 10. For comparison, the results of hydraulic conductivity testing on the unamended liner composite, conducted at $90 \%$ of proctor, and the unamended liner plus 5 and $10 \mathrm{wt} \%$ additions of sand are also included.

A single value is reported for each hydraulic conductivity test in Table 10 because in all cases, including both the liner attenuation and tailings leaching column studies, no change in hydraulic conductivity was recorded over time. The average pressure head applied during the attenuation studies was $35 \mathrm{~cm}$ for attenuation Column №. $1,84 \mathrm{~cm}$ for attenuation Column №. 2 and $\sim 1,530 \mathrm{~cm}$ for leaching Columns No. 1 and No. 2. For comparison, the unamended composite and the composite plus sand amendments were tested for permeability using tap water and a falling head method with a maximum head of $50 \mathrm{~cm}$. The stability of the attenuation column flow rates over time indicates that the hydraulic performance of the Canonsburg liner will not be degraded because of 
TABLE 10. Permeability Results from the Attenuation and Leaching Columns Plus Standardized Testing of the Unamended and the Composite Plus Sand Amendments

\begin{tabular}{|c|c|c|c|}
\hline Test Material & $\begin{array}{c}\text { Dry- } \\
\text { Bulk Denşity, } \\
\mathrm{g} / \mathrm{cm}^{3} \\
\end{array}$ & Flow Solution & $\begin{array}{c}\text { Hydraulic } \\
\text { Conductivity, } \\
\mathrm{cm} / \mathrm{s} \\
\end{array}$ \\
\hline $\begin{array}{l}\text { Attenuation } \\
\text { Column No. } 1\end{array}$ & 1.60 & Solution II & $2.1 \times 10^{-6}$ \\
\hline $\begin{array}{l}\text { Attenuation } \\
\text { Column No. } 2\end{array}$ & 1.60 & Solution I & $9.6 \times 10^{-7}$ \\
\hline $\begin{array}{l}\text { Leaching } \\
\text { Column No. } 1\end{array}$ & 1.30 & Deionized Water & $4.8 \times 10^{-8}$ \\
\hline $\begin{array}{l}\text { Leaching } \\
\text { Column No. } 2\end{array}$ & 1.30 & Deionized Water & $1.6 \times 10^{-8}$ \\
\hline $\begin{array}{l}\text { Unamended } \\
\text { Composite }\end{array}$ & 1.91 & Tap Water & $3.6 \times 10^{-8}$ \\
\hline $\begin{array}{l}\text { Composite } \\
\text { Plus } 5 \% \text { Sand }\end{array}$ & 1.91 & Tap Water & $4.5 \times 10^{-8}$ \\
\hline $\begin{array}{l}\text { Composite } \\
\text { Plus } 10 \% \text { Sand }\end{array}$ & 1.91 & Tap Water & $4.4 \times 10^{-8}$ \\
\hline
\end{tabular}

long-term contact with leachate solutions from the Canonsburg tailings. Also, sand additions (up to $10 \%$ by weight) failed to dramatically increase the permeability of the unamended composite.

of particular interest are the hydraulic conductivity data presented in Table 10 for the two tailings leaching columns. Even when only hand packed to a dry-bulk density of $1.3 \mathrm{~g} / \mathrm{cm}^{3}$, the solid tailings proved to be highly impermeable. This agrees with the result of Marcos, Bush and Freeman (1981) who suggested that either a perched water table or a shallow, subsurface water dome exists in the tailings area as a result of very low hydraulic conductivity and the slow flow rate of water within the tailings. They state that low hydraulic conductivity is also suggested by the dense and compacted clayey soil in the tailings area as well as by the slow recharge rate observed after pumping water out of the wells for sampling. Although the low hydraulic conductivity of the solid tailings is favorable for the retention of contaminants in the 
tailings themselves, it will pose a problem in the encapsulation system if excess infiltration water pools on top of the tailings rather than passing through the encapsulation cell and out the bottom liner. The potential for water ponding suggests that the drainage characteristics of the tailings should be measured and that the effects of potential tailings amendments be tested before actual placement of the tailings in the proposed cover configuration. A potential option in waste placement design would be to surround the waste and liner with a coarse permeable rock barrier. Water percolating vertically or moving laterally through the soil could be short-circuited around the waste pile as long as the pile remained above the water table (See Figure 4; Gee, Rai and Serne 1983).

An estimate of the flow through the liner in terms of pore volumes of effluent can be made as follows: the volume, $V_{p}$, of the pore space of the liner is

$$
V_{P}=V_{T} P=A L P
$$

where

$$
\begin{aligned}
V_{T} & =\text { total liner volume }\left(\mathrm{cm}^{3}\right) \\
P & =\text { total porosity (unitless) } \\
A & =1 \text { iner area }\left(\mathrm{cm}^{2}\right) \\
L & =1 \text { iner thickness }(\mathrm{cm}) .
\end{aligned}
$$

The number, $n$, of pore volumes of effluent passing through the liner in a given time is:

$$
n=Q / V_{P}=Q / A L P
$$

where

$$
Q=\text { total effluent volume. }
$$


Using Darcy's Law for flow of effluent through the liner, we can express the time dependence of effluent pore volumes as follows:

$$
\begin{gathered}
n=Q / A L P=\frac{1}{L P}\left(K \frac{\Delta H}{L}\right) \Delta T \\
\Delta T=\frac{n L P}{K} \quad \frac{L}{\Delta H}
\end{gathered}
$$

Hence,

where

$$
\begin{aligned}
K & =\text { liner hydraulic conductivity }(\mathrm{cm} / \mathrm{s}) \\
\Delta H & =\text { hydraulic head difference across liner }(\mathrm{cm}) \\
\Delta T & =\text { time }
\end{aligned}
$$

From the preceeding equation, Gee et al. (1980) predicted that for a compacted clay liner $1 \mathrm{~m}$ thick with a hydraulic conductivity of $10^{-8} \mathrm{~cm} / \mathrm{s}$, the maximum flow through a tailings pond liner would be less than 2 pore volumes in 20 years (assuming a hydraulic gradient of 10). For the Canonsburg disposal design, a unit gradient $(\Delta H / L \cong 1)$ assumption is reasonable; hence, for 1-mthick liner, 2.0 pore volumes of flow through material with a low permeability $\left(10^{-8} \mathrm{~cm} / \mathrm{s}\right)$ would require at least 250 years.

At a permeability of $5 \times 10^{-8} \mathrm{~cm} / \mathrm{s}$, which is higher than any we measured for the compacted liner materials (Table 10), about 10 pore volumes of fluid would seep through the liner in 250 years. Extrapolating results from the observed flow through columns (Tables B.1 to B.6), we suggest that little change in liner chemistry or permeability would be expected in 250 years. However, since only 3 pore volumes were tested additional column analysis would be required to confirm these extrapolated results.

Another design option would be to compact the tailings as tightly as possible. The tailings appear to have a very low hydraulic conductivity $\left(<10^{-8} \mathrm{~cm} / \mathrm{s}\right)$ and reduced flow through the tailings would reduce the potential leaching hazard. Studies should be undertaken to investigate the effects of compaction on leaching of the Canonsburg tailings. 


\section{REFERENCES}

Alexander, L. T., and H. G. Byers. 1932. "A Critical Laboratory Review of Methods of Determining Organic Matter and Carbonates in Soil." Tech. Bul1. 317, U.S. Dept. of Agriculture, U.S. Government Printing Office, Washington, D.C.

ASTM. 1982. Annual Book of ASTM Standards Part 19. American Society for Testing and Materials, Philadelphia, Pennsylvania.

Black, C. A. 1965. "Methods of Soil Analysis. Part 1. Physical and Mineralogical Properties Including Statistics of Measurement and Sampling." Monograph 9, American Society of Agronomy, Madison, Wisconsin.

Bohn, H. L., B. L. McNeal and G. A. O'Connor. 1979. Soil Chemistry. p. 184. John Wiley and Sons, Inc., New York.

DOE. 1982. Annual Status Report on the Uranium Mill Tailings Remedial Action Program. DOE/NE-0025/1, U.S. Department of Commerce. Springfield, Virginia.

Ediger, R. D. 1975. "Atomic Absorption Analysis with the Graphite Furnace Using Matrix Modification." Atomic Absorption Newsletter 14(15):127-130.

EPA. 1978. "Hazardous Waste, Proposed Guidelines and Regulations and Proposal on Identification and Listing." 43(243):58946-59026 Fed. Reg.

EPA. 1979. "U.S. Environmental Protection Agency, 40 CFR 143, National Secondary Drinking Water Regulations." 44:42198 Fed. Reg. (July 19, 1979).

EPA. 1980. "U.S. Environmental Protection Agency, 40 CFR 141, National Interim Primary Drinking Water Standards." - 45:57342 Fed. Reg. (August 27, 1980).

Fuller, W. H. 1981. Liners of Natural Porous Materials to Minimize Pollutant Migration. EPA-600/52-81-122, Municipal Environmental Research Laboratory, Cincinnati, Ohio.

Gee, G. W., A. C. Campbell, 0. R. Sherwood, R. G. Strickert and S. J. Phillips. 1980. Interaction of Uranium Mill Tailings Leachates with Soils and Clay Liners. NUREG/CR-1494 (PNL-3381), Nuclear Regulatory Commission, Washington, D.C.

Gee, G. W., Dhanpat Rai and R. J. Serne. 1983. "Mobility of Radionuclides in Soil." In Chemical Mobility and Reactivity in Soil Systems. ed. D. W. Nelson, P. 219, Special ASA Publication II. ASA, Madison, Wisconsin.

Heilman, M. D., O. L. Carter and C. L. Gonzales. 1965. "The Ethylene Glycol Monoethyl Ether (EGME): Technique for Determining Soil Surface Area." Soil Science $100(6): 409-413$. 
Jenne, E. A. 1968. "Controls on $\mathrm{Mn}, \mathrm{Fe}, \mathrm{Co}, \mathrm{Ni}, \mathrm{Cu}$, and $\mathrm{Zn}$ Concentrations in Soils and Water: The Significant Role of Hydrous Mn and Fe Oxides." Adv. Chem. Ser. 73:337-387.

Kilmer, V. J. 1960. "The Estimation of Free Iron Oxides in Soils." Soil Sci. Soc. Am. Proc. 24:520.

Klages, M. G. and R. W. Hopper. 1982. "Clay Minerals in Northern Plains Coal Overburden as Measured by X-ray Diffraction." Soil Sci. Soc. Am. J. 46:415-419.

Korte, N. E., J. Skopp, E. E. Niebla and W. H. Fuller. 1975. "A Baseline Study on Trace Metal Elution from Diverse Soil Types." Water Air Soil Pollut. 5:149-156.

Levins, D. M., R. K. Ryan and K. P. Strong. 1978. "Leaching of Radium from Uranium Tailings." Paper presented at Seminar on Management, Stabilization and Environmental Impact of Uranium Mill Tailings, July 1978, Albuquerque, New Mexico.

Marcos, G., K. J. Bush and T. Freeman. 1981. Geochemical Investigation of UMTRAP Designated Site at Canonsburg, Pennsylvania. UMTRA-DOE/AL0-226, GECR \#-811, University of Colorado, Denver, Colorado.

Martin, T. D., et al. 1975. "Determining Selenium in Water, Wastewater, Sediment, and Siudge by Flameless Atomic Absorption Spectroscopy." Atomic Absorption Newsletter 14(5):109-115.

NRC. 1979. "U.S. Nuclear Regulatory Commission, 10 CFR 20, Standards for Protection Against Radiation." 44:63515 Fed. Reg.

NRC. 1980. Final Generic Environmental Impact Statement on Uranium Milling. Vol. 1, NUREG/CR-0706, Office of Nuclear Material Safety and Safeguards, Nuclear Regulatory Commission, Washington, D.C.

Richards, L. A., (ed.). 1954. "Saline and Alkali Soils." USDA Handbook No. 60, U.S. Government Printing office, Washington, D.C.

Serne, R. J., S. R. Peterson and G. W. Gee. 1983. Laboratory Measurements of Contaminant Attenuation of Uranium Mill Tailings Leachates by Sediments and Clay Liners. NUREG/CR-3124 (PNL-4605), Nuclear Regulatory Commission, Washington, D.C.

Slavin, W. and D. C. Manning. 1979. "Reduction of Matrix Interferences for Lead Oetermination with the L'Vov Platform and Graphite Furnace." Anal. Chem. 51:261-266. 



\section{APPENDIX A}

CHEMICAL ANALYSIS OF 1:1 WATER EXTRACTS FRDM UNAMENDED AND IRON- AND MANGANESE-AMENDED COMPOSITES 
TABLE A.1. Chemical Analysis of 1:1 Water Extracts from Unamended and Iron- and Manganese-Amended Composites

\begin{tabular}{|c|c|c|c|}
\hline Parameter & $\begin{array}{l}\text { Liner Mix } \\
1: 1 \text { Extract }\end{array}$ & $\begin{array}{c}\text { Mix }+ \text { Fe Oxide } \\
1: 1 \text { Extract }\end{array}$ & $\begin{array}{c}\text { Mix }+ \text { Mn Zeolite } \\
1: 1 \text { Extract }\end{array}$ \\
\hline $\begin{array}{l}\mathrm{pH} \text { (pH units) } \\
\text { Eh (tmV) } \\
\mathrm{EC}(\mu \mathrm{mhhos})\end{array}$ & $\begin{array}{r}4.70 \\
504 \\
0.83\end{array}$ & $\begin{array}{r}3.71 \\
459 \\
0.97\end{array}$ & $\begin{array}{r}4.75 \\
479 \\
0.92\end{array}$ \\
\hline
\end{tabular}

Macro Ions (ppm)

$\begin{array}{lrrr}\mathrm{A} 1 & 0.28 & 0.39 & 0.38 \\ \mathrm{~B} & 0.15 & 0.06 & 0.12 \\ \mathrm{Ba} & 0.03 & 0.03 & 0.05 \\ \mathrm{Ca} & 87.6 & 107 & 99.2 \\ \mathrm{Fe} & 0.02 & 0.04 & 0.03 \\ \mathrm{~K} & 13.3 & 14.5 & 18.5 \\ \mathrm{Li} & 0.06 & 0.06 & 0.06 \\ \mathrm{Mg} & 47.5 & 55.6 & 50.3 \\ \mathrm{Na} & 19.3 & 17.2 & 28.8 \\ \mathrm{P} & 0.13 & 0.21 & 0.18 \\ \mathrm{~S} & 170 & 196 & 194 \\ \mathrm{Si} & 23.0 & 23.2 & 29.7 \\ \mathrm{Sr} & 0.33 & 0.38 & 0.36 \\ \mathrm{Cl} & 4.1 & 4.0 & 3.4 \\ \mathrm{~F} & <1.5 & <1.5 & <1.5 \\ \mathrm{NO}{ }_{3} & 7.5 & 23 & 8.3 \\ \mathrm{SO}_{4} & 450 & 520 & 520\end{array}$

Trace Metais (ppm)

$\begin{array}{lrrr}\text { As } & 0.01 & 0.01 & 0.01 \\ \mathrm{Cr} & 0.02 & 0.02 & 0.02 \\ \mathrm{Mo} & 0.01 & 0.01 & 0.01 \\ \mathrm{Ni} & 0.11 & 0.13 & 0.12 \\ \mathrm{Se} & <0.01 & <0.01 & <0.01 \\ \text { V } & 0.01 & 0.01 & 0.02 \\ \text { Zn } & 0.24 & 0.34 & 0.25 \\ \mathrm{Zr} & 0.01 & 0.01 & 0.01\end{array}$





\section{APPENDIX B}

CHEMICAL COMPOSITION OF ATTENUATION COLUMN AND LEACHING COLUMN EFFLUENTS 
TABLE B.1. Chemical Analysis of Effluent Solutions from Attenuation Column No. 1 (Unamended Mix Contacted with Solution II)

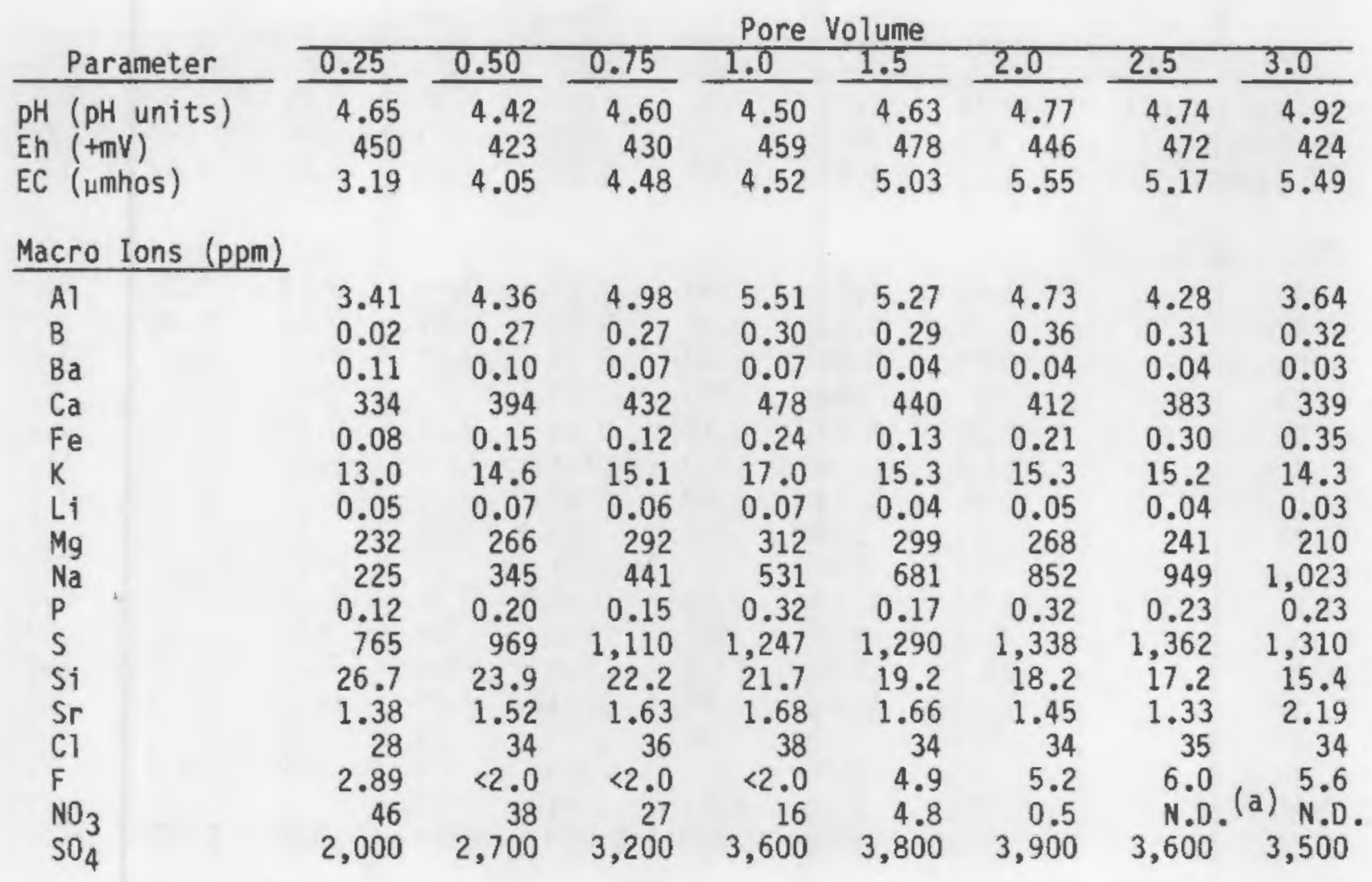

\section{Trace Metals (ppm)}

$\begin{array}{lrrrrrrrr}\text { As } & <0.02 & <0.02 & <0.02 & <0.02 & <0.02 & <0.02 & <0.02 & <0.02 \\ \text { Cd } & 0.02 & 0.02 & 0.02 & 0.02 & 0.02 & 0.02 & 0.01 & 0.01 \\ \text { Ce } & 0.13 & 0.53 & 0.49 & 0.86 & 0.19 & 0.46 & 0.47 & 0.19 . \\ \text { Co } & 0.15 & 0.19 & 0.15 & 0.20 & 0.25 & 0.26 & 0.25 & 0.21 \\ \text { Cr } & <0.01 & <0.01 & <0.01 & <0.01 & <0.01 & <0.01 & <0.01 & <0.01 \\ \text { Cu } & 0.05 & 0.02 & 0.07 & 0.05 & 0.04 & 0.05 & <0.02 & <0.02 \\ \mathrm{Mo} & <0.02 & <0.02 & <0.02 & <0.02 & <0.02 & <0.02 & <0.02 & <0.02 \\ \mathrm{Ni} & 0.49 & 0.63 & 0.69 & 0.79 & 0.67 & 0.65 & 0.63 & 0.53 \\ \mathrm{~Pb} & 0.03 & 0.02 & 0.04 & 0.02 & 0.02 & <0.02 & <0.02 & <0.02 \\ \mathrm{Se} & <0.02 & <0.02 & <0.02 & <0.02 & <0.02 & <0.02 & <0.05 & <0.05 \\ \text { y } & 0.01 & 0.04 & 0.03 & 0.05 & 0.01 & 0.03 & 0.03 & 0.01 \\ \mathrm{Zn} & 3.18 & 3.03 & 3.23 & 3.64 & 2.89 & 2.60 & 2.13 & 1.70 \\ \mathrm{Zr} & 0.01 & 0.02 & 0.02 & 0.03 & <0.01 & 0.02 & 0.02 & <0.01\end{array}$

Radionuclides

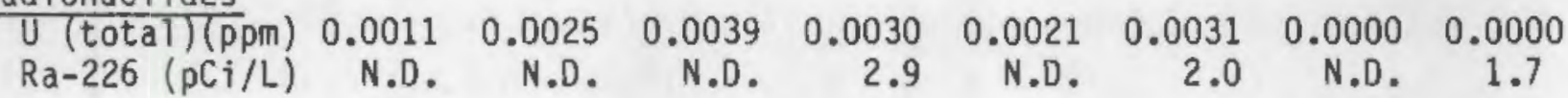

\footnotetext{
(a) N.D. = Not Determined
} 
TABLE B.2. Chemical Analysis of Effluent Solutions from Attenuation Column No. 2 (Unamended Composite Contacted with Solution I)

\begin{tabular}{|c|c|c|c|c|c|c|c|c|}
\hline & & & & Pore & Volume & & & \\
\hline Parameter & 0.25 & 0.50 & 0.75 & 1.0 & 1.5 & 2.0 & 2.5 & 3.0 \\
\hline $\mathrm{pH}$ (pH units) & 4.78 & 4.54 & 4.99 & 5.08 & 7.98 & 8.25 & 8.38 & 8.23 \\
\hline Eh $(+m V)$ & 413 & 472 & 542 & 438 & 313 & 297 & 284 & 292 \\
\hline EC (umhos) & 2.93 & 3.41 & 3.45 & 3.58 & 3.28 & 2.77 & 3.12 & 3.05 \\
\hline Macro Ions ( $p$ & & & & & & & & \\
\hline A1 & 2.62 & 3.33 & 2.83 & 1.97 & 0.54 & 0.14 & 0.25 & 0.13 \\
\hline B & 0.31 & 0.23 & 0.28 & 0.34 & 0.43 & 0.43 & 0.48 & 0.48 \\
\hline $\mathrm{Ba}$ & 0.07 & 0.04 & 0.03 & 0.03 & 0.04 & 0.06 & 0.05 & 0.04 \\
\hline $\mathrm{Ca}$ & 337 & 364 & 358 & 353 & 282 & 242 & 240 & 225 \\
\hline $\mathrm{Fe}$ & 0.08 & 0.19 & 0.15 & 0.19 & 0.34 & 0.12 & 0.10 & 0.14 \\
\hline$k$ & 13.0 & 12.9 & 13.0 & 13.7 & 12.3 & 12.1 & 11.6 & 11.2 \\
\hline Li & 0.05 & 0.03 & 0.03 & 0.02 & 0.02 & $<0.01$ & 0.01 & $<0.01$ \\
\hline $\mathrm{Mg}$ & 199 & 233 & 215 & 183 & 118 & 71 & 79 & 71 \\
\hline $\mathrm{Na}$ & 243 & 239 & 333 & 401 & 447 & 493 & 503 & 512 \\
\hline$P$ & 0.10 & 0.09 & 0.08 & 0.12 & 0.28 & 0.04 & 0.13 & 0.01 \\
\hline$S$ & 713 & 822 & 865 & 811 & 704 & 636 & 645 & 631 \\
\hline $\mathrm{Si}$ & 20.3 & 21.6 & 17.9 & 15.2 & 10.7 & 7.79 & 7.86 & 7.35 \\
\hline $\mathrm{Sr}$ & 1.22 & 1.35 & 1.25 & 1.11 & 0.85 & 0.74 & 0.71 & 0.68 \\
\hline $\mathrm{Cl}$ & 33 & 30 & 36 & 33 & 31 & 31 & 31 & 30 \\
\hline $\mathrm{F}$ & $<2$ & 2.8 & 3.7 & 3.0 & 2.4 & 2.2 & 2.2 & 2.1 \\
\hline $\mathrm{NO}_{3}$ & 32 & 3.9 & N.D. & $<1$ & $<1$ & $<1$ & $<1$ & $<1$ \\
\hline $\mathrm{SO}_{4}$ & 2,200 & 2,100 & 2,300 & 2,300 & 1,800 & 1,500 & 1,600 & 1,600 \\
\hline
\end{tabular}

Trace Metals (ppm)

$\begin{array}{lrrrrrrrr}\text { As } & <0.02 & <0.02 & <0.02 & <0.02 & 0.04 & 0.15 & N . D . & N . D \text {. } \\ \text { Cd } & 0.03 & 0.01 & 0.02 & <0.01 & <0.01 & <0.01 & <0.01 & <0.01 \\ \text { Ce } & 0.50 & 0.07 & 0.23 & 0.22 & 0.29 & 0.02 & 0.24 & 0.10 \\ \mathrm{Co} & 0.16 & 0.22 & 0.20 & 0.17 & 0.17 & 0.13 & 0.13 & 0.09 \\ \mathrm{Cr} & <0.01 & <0.01 & <0.01 & <0.01 & <0.01 & <0.01 & <0.01 & <0.01 \\ \mathrm{Cu} & 0.22 & 0.05 & <0.02 & <0.02 & <0.02 & <0.02 & <0.02 & <0.02 \\ \mathrm{Mo} & 0.03 & <0.02 & <0.02 & <0.02 & 0.10 & 0.21 & 0.18 & 0.15 \\ \mathrm{Ni} & 0.51 & 0.54 & 0.52 & 0.43 & 0.28 & 0.21 & 0.24 & 0.14 \\ \mathrm{~Pb} & <0.02 & <0.02 & <0.02 & <0.02 & <0.02 & <0.02 & <0.02 & <0.02 \\ \mathrm{Se} & <0.02 & <0.02 & <0.02 & <0.02 & <0.02 & <0.02 & <0.02 & <0.02 \\ \mathrm{~V} & 0.04 & 0.01 & 0.02 & 0.02 & 0.03 & 0.01 & 0.02 & 0.01 \\ \mathrm{Zn} & 0.94 & 0.92 & 0.87 & 0.93 & 1.41 & 0.60 & 0.92 & 1.09 \\ \mathrm{Zr} & 0.02 & <0.01 & <0.01 & 0.01 & 0.02 & <0.01 & 0.01 & <0.01\end{array}$

Radionuclides

$\begin{array}{rlrrrrrrr}U(\operatorname{tota})(p p m) & 0.240 & 0.021 & 0.047 & 0.076 & 0.720 & 1.730 & 1.230 & 1.190 \\ R a-226(p C i / L) & \text { N.D. (a) } & \text { N.D. } & \text { N.D. } & 13.8 & \text { N.D. } & 42.8 & \text { N.D. } & 62.3\end{array}$

(a) N.D. = Not Oetermined 
TABLE B.3. Chemical Analysis of Effluent Solutions from Attenuation Column No. 3 (Composite Plus 2\% Fe 0xide Contacted with Solution II)

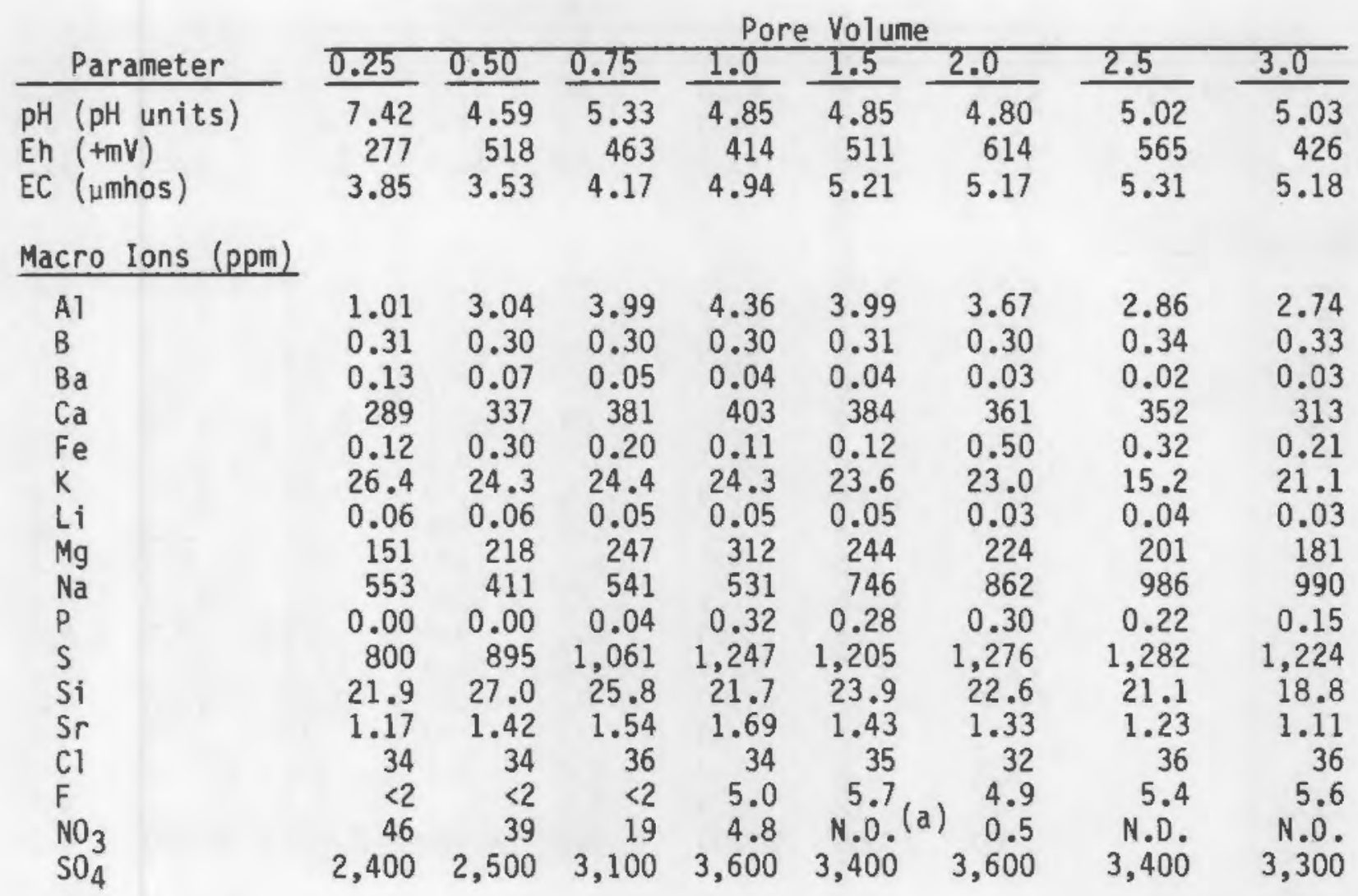

\section{Trace Metals (ppm)}

$\begin{array}{lrrrrrrrr}\text { As } & 0.07 & <0.02 & <0.02 & <0.02 & <0.02 & <0.02 & <0.02 & <0.02 \\ \text { Cd } & 0.01 & 0.01 & 0.02 & 0.02 & 0.02 & 0.02 & 0.01 & 0.01 \\ \text { Ce } & <0.06 & <0.06 & <0.06 & <0.06 & 0.21 & 0.23 & 0.65 & 0.21 \\ \text { Co } & 0.10 & 0.08 & 0.09 & 0.09 & 0.13 & 0.16 & 0.16 & 0.14 \\ \text { Cr } & <0.01 & <0.01 & <0.01 & <0.01 & <0.01 & <0.01 & <0.01 & <0.01 \\ \text { Cu } & <0.02 & <0.02 & <0.02 & <0.02 & <0.02 & <0.02 & <0.02 & <0.02 \\ \text { Mo } & 0.34 & <0.02 & <0.02 & <0.02 & <0.02 & <0.02 & <0.02 & <0.02 \\ \mathrm{Ni} & 0.36 & 0.46 & 0.52 & 0.79 & 0.57 & 0.57 & 0.55 & 0.47 \\ \mathrm{~Pb} & <0.02 & <0.02 & <0.02 & <0.02 & <0.02 & <0.02 & <0.02 & <0.02 \\ \mathrm{Se} & <0.02 & <0.02 & <0.02 & <0.02 & <0.02 & <0.02 & <0.03 & <0.02 \\ \text { i } & <0.01 & <0.01 & 0.01 & <0.01 & 0.02 & 0.01 & 0.01 & 0.01 \\ \text { Zn } & 0.46 & 0.61 & 0.74 & 0.74 & 0.76 & 0.71 & 0.67 & 0.61 \\ \text { Zr } & <0.01 & <0.01 & <0.01 & <0.01 & <0.01 & <0.01 & <0.01 & <0.01\end{array}$

Radionuclides

$\begin{array}{lllllllll}U \text { (total) ppm } & 0.98 & 0.31 & 0.14 & 0.11 & 0.150 & 0.0587 & 0.0375 & 0.0285\end{array}$

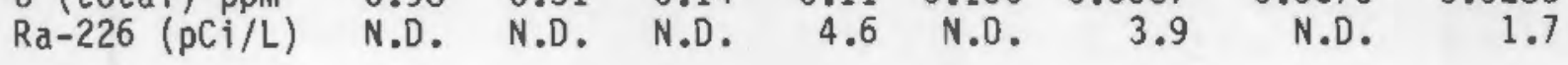

(a) N.D. = Not Determined 
TABLE B.4. Chemical Analysis of Effluent Solutions from Attenuation Column No. 4 (Composite Plus 2\% Fe 0xide Contacted with Tailings Solution I)

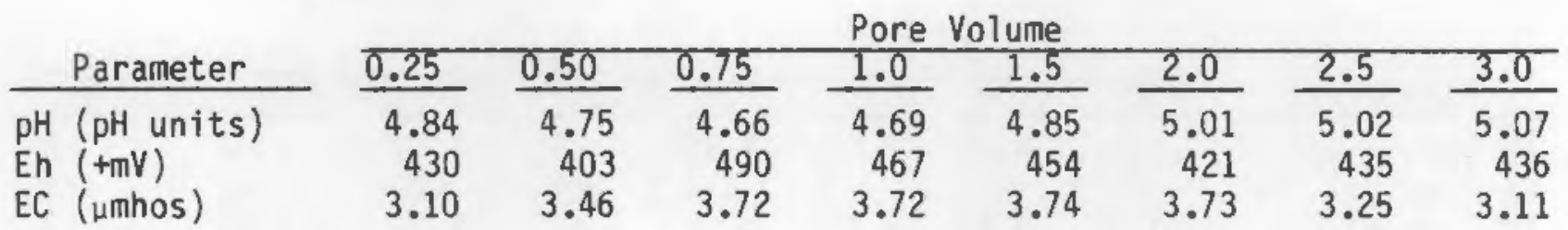

Macro Ions ( $\rho \mathrm{pm})$

$\begin{array}{lrrrrrrrl}\mathrm{Al} & 2.41 & 3.04 & 3.37 & 3.45 & 3.26 & 2.74 & 2.16 & \text { N.D. (a) } \\ \mathrm{B} & 0.28 & 0.27 & 0.27 & 0.32 & 0.32 & 0.38 & 0.31 & \text { N.D. } \\ \mathrm{Ba} & 0.08 & 0.06 & 0.05 & 0.05 & 0.03 & 0.03 & 0.03 & \text { N.D. } \\ \mathrm{Ca} & 276 & 310 & 333 & 348 & 352 & 309 & 259 & \text { N.D. } \\ \mathrm{Fe} & 0.05 & 0.07 & 0.15 & 0.09 & 0.06 & 0.10 & 0.11 & \text { N.D. } \\ \mathrm{K} & 19.4 & 19.2 & 19.7 & 19.7 & 18.8 & 17.6 & 16.0 & \text { N.D. } \\ \mathrm{Li} & 0.05 & 0.04 & 0.04 & 0.05 & 0.02 & 0.02 & 0.04 & \text { N.D. } \\ \mathrm{Mg} & 180 & 204 & 217 & 216 & 206 & 180 & 149 & \text { N.O. } \\ \mathrm{Na} & 211 & 285 & 327 & 357 & 433 & 480 & 468 & \text { N.D. } \\ \mathrm{P} & 0.00 & 0.16 & 0.21 & 0.32 & 0.07 & 0.03 & 0.30 & \text { N.D. } \\ \mathrm{S} & 609 & 763 & 834 & 880 & 924 & 878 & 812 & \text { N.D. } \\ \mathrm{Si} & 28.8 & 26.7 & 26.6 & 26.2 & 25.3 & 24.2 & 23.1 & \text { N.D. } \\ \mathrm{Sr} & <02 & <0.02 & <0.02 & <0.02 & <0.02 & <0.02 & <0.02 & \text { N.D. } \\ \mathrm{Cl} & 30 & 30 & 30 & 32 & 32 & 33 & 38 & \text { N.D. } \\ \mathrm{F} & 2.8 & 2.8 & 1.8 & 3.2 & 3.1 & 3.1 & 2.6 & \text { N.D. } \\ \mathrm{NO}_{3} & 18 & 5.9 & 0.4 & <1 & 3.8 & <1 & \text { N.D. } \\ \mathrm{SO}_{4} & 1,700 & 2,000 & 2,200 & 2,500 & 2,700 & 2,400 & 2,000 & \text { N.D. }\end{array}$

Trace Metals (ppm)

$\begin{array}{lrrrrrrrr}\text { As } & <0.02 & <0.02 & <0.02 & <0.02 & <0.02 & <0.02 & \text { N.D. } & \text { N.D. } \\ \text { Cd } & 0.02 & 0.02 & 0.01 & 0.02 & 0.02 & 0.04 & \text { N.D. } & \text { N.D. } \\ \text { Ce } & 0.03 & 0.00 & 0.03 & 0.05 & 0.09 & 0.17 & \text { N.D. } & \text { N.D. } \\ \text { Co } & 0.08 & 0.12 & 0.11 & 0.14 & 0.16 & 0.17 & \text { N.D. } & \text { N.D. } \\ \text { Cr } & <0.01 & <0.01 & <0.01 & <0.01 & <0.01 & <0.01 & \text { N.D. } & \text { N.D. } \\ \text { Cu } & <0.02 & <0.02 & 0.02 & <0.02 & <0.02 & 0.03 & \text { N.D. } & \text { N.D. } \\ \text { Mo } & <0.02 & <0.02 & <0.02 & <0.02 & <0.02 & <0.02 & \text { N.D. } & \text { N.D. } \\ \text { Ni } & 0.41 & 0.46 & 0.50 & 0.56 & 0.49 & 0.59 & 0.41 & \text { N.0. } \\ \text { Pb } & <0.02 & <0.02 & <0.02 & <0.02 & <0.02 & 0.07 & \text { N.D. } & \text { N.D. } \\ \text { Se } & <0.02 & <0.02 & <0.02 & <0.02 & <0.02 & <0.02 & \text { N.0. } & \text { N.D. } \\ \text { V } & 0.01 & 0.01 & 0.01 & 0.04 & 0.01 & 0.01 & 0.04 & \text { N.D. } \\ \text { Zn } & 0.69 & 0.67 & 0.76 & 0.82 & 1.28 & 2.05 & 1.14 & \text { N.D. } \\ \text { Zr } & <0.01 & <0.01 & <0.01 & 0.02 & <0.01 & 0.01 & 0.02 & \text { N.D. }\end{array}$

Radionuclides

$\begin{array}{llllllll}U \text { (total) ppm } & 0.05 & 0.01 & 0.004 & 0.004 & 0.002 & 0.003 & 0.000\end{array}$

(a) N.D. = Not Determined 
TABLE B.5. Chemical Analysis of Effluent Solutions from Attenuation Column No. 5 (Composite Plus $2 \%$ Mn Zeolite Contacted with Tailings Solution II)

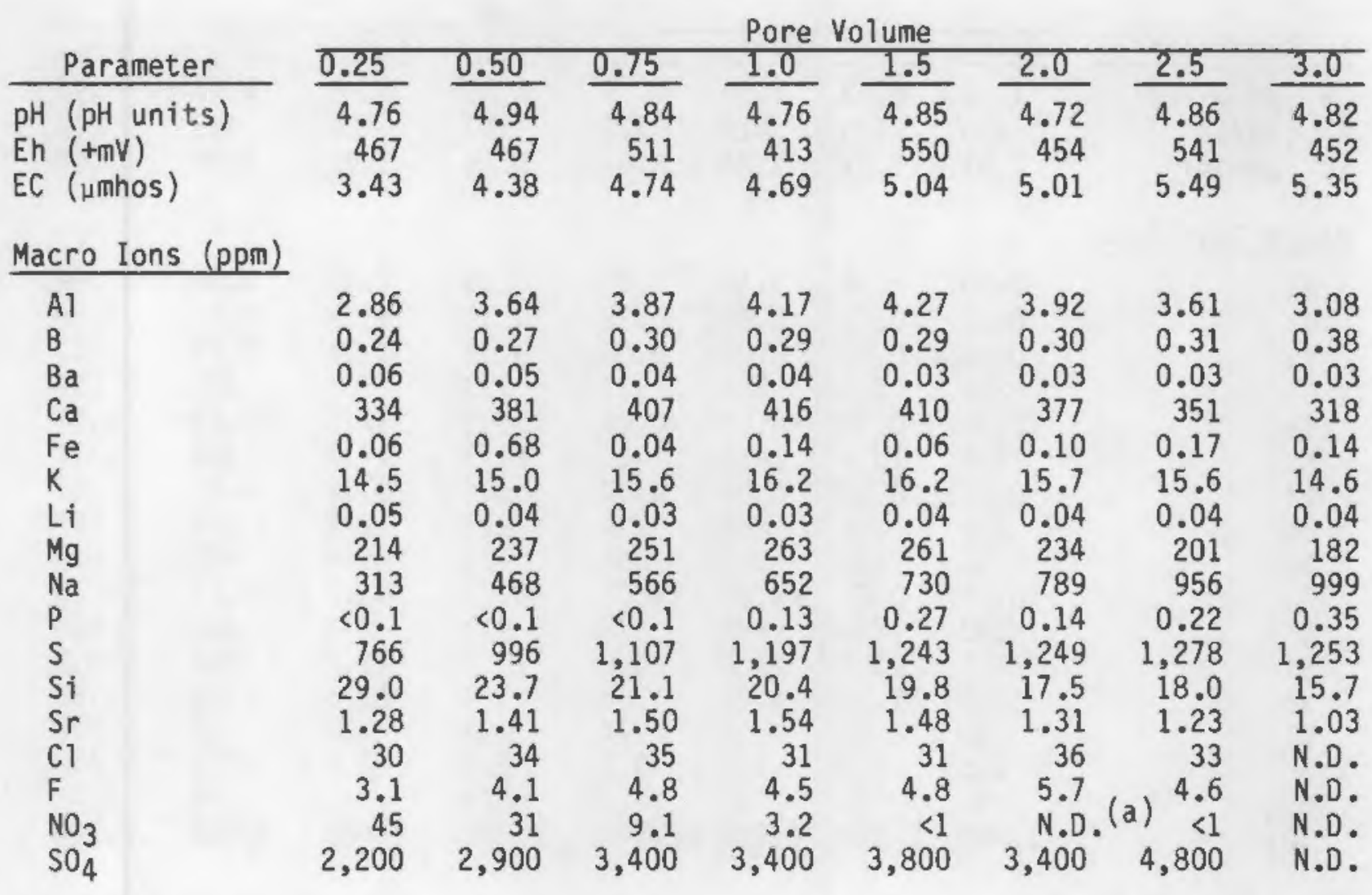

Trace Metals (ppm)

$\begin{array}{lrrrrrrrr}\text { As } & <0.02 & <0.02 & <0.02 & <0.02 & <0.02 & <0.02 & <0.02 & <0.02 \\ \text { Cd } & 0.02 & 0.02 & 0.02 & 0.02 & 0.02 & 0.02 & 0.02 & 0.02 \\ \text { Ce } & 0.13 & 0.12 & 0.05 & 0.05 & 0.15 & 0.47 & 0.28 & 0.54 \\ \text { Co } & 0.20 & 0.17 & 0.23 & 0.23 & 0.26 & 0.29 & 0.28 & 0.25 \\ \text { Cr } & <0.01 & <0.01 & <0.01 & <0.01 & <0.01 & <0.01 & <0.01 & <0.01 \\ \text { Cu } & 0.03 & 0.02 & <0.02 & 0.04 & <0.02 & <0.02 & <0.02 & <0.02 \\ \mathrm{Mo} & 0.01 & 0.01 & 0.01 & 0.01 & 0.01 & 0.01 & 0.01 & 0.04 \\ \mathrm{Ni} & 0.55 & 0.61 & 0.63 & 0.64 & 0.66 & 0.63 & 0.55 & 0.58 \\ \mathrm{~Pb} & <0.02 & <0.02 & <0.02 & <0.02 & <0.02 & <0.02 & <0.02 & <0.02 \\ \mathrm{Se} & <0.02 & <0.02 & <0.02 & <0.02 & <0.02 & <0.02 & <0.02 & <0.02 \\ \mathrm{~V} & 0.01 & 0.01 & 0.01 & 0.00 & 0.01 & 0.03 & 0.02 & 0.03 \\ \mathrm{Zn} & 0.87 & 0.88 & 0.86 & 0.83 & 0.82 & 0.75 & 0.69 & 0.80 \\ \mathrm{Zr} & <0.01 & <0.01 & <0.01 & <0.01 & <0.01 & 0.02 & 0.01 & 0.01\end{array}$

Radionuclides

$\begin{array}{llllllllr}U \text { (total) ppm } & 0.19 & 0.14 & 0.17 & 0.14 & 0.108 & 0.068 & 0.034 & 0.031 \\ \operatorname{Ra}-226(\mathrm{pCi} / \mathrm{L}) & \text { N.D. } & \text { N.D. } & \text { N.0. } & 17.3 & \text { N.D. } & 1.4 & \text { N.D. } & 3.5\end{array}$

(a) N.D. = Not Determined 
TABLE B.6. Chemical Analysis of Effluent Solutions from Attenuation Column No. 6 (Composite Plus 2\% Mn 0xide Contacted with Tailings Solution I)

\begin{tabular}{|c|c|c|c|c|c|c|c|c|}
\hline & & & & Pore & Volume & & & \\
\hline Parameter & 0.25 & 0.50 & 0.75 & 1.0 & 1.5 & 2.0 & 2.5 & 3.0 \\
\hline $\mathrm{pH}$ (pH units) & 4.54 & 4.63 & 4.53 & 4.75 & 4.68 & 4.75 & 4.74 & 4.99 \\
\hline Eh $(+m V)$ & 420 & 423 & 413 & 422 & 410 & 426 & 413 & 418 \\
\hline EC (umhos) & 2.87 & 3.21 & 3.24 & 3.64 & 3.75 & 3.92 & 3.94 & 3.59 \\
\hline Macro Ions ( $p$ & & & & & & & & \\
\hline A1 & 2.29 & 2.92 & 3.18 & 3.28 & 3.23 & 2.83 & 2.38 & 2.02 \\
\hline B & 0.25 & 0.29 & 0.29 & 0.29 & 0.32 & 0.36 & 0.39 & 0.36 \\
\hline $\mathrm{Ba}$ & 0.12 & 0.09 & 0.06 & 0.05 & 0.05 & 0.04 & 0.03 & 0.03 \\
\hline $\mathrm{Ca}$ & 265 & 316 & 332 & 337 & 333 & 309 & 274 & 250 \\
\hline $\mathrm{Fe}$ & $<0.06$ & 0.38 & $<0.06$ & $<0.06$ & $<0.06$ & 0.05 & 0.14 & 0.17 \\
\hline$k$ & 12.5 & 13.8 & 14.2 & 14.0 & 13.9 & 14.0 & 13.4 & 13.1 \\
\hline Li & 0.05 & 0.06 & 0.04 & 0.03 & 0.04 & 0.04 & 0.03 & 0.03 \\
\hline $\mathrm{Mg}$ & 184 & 208 & 226 & 231 & 223 & 205 & 176 & 157 \\
\hline $\mathrm{Na}$ & 191 & 250 & 317 & 361 & 434 & 505 & 540 & 556 \\
\hline$P$ & $<0.01$ & 0.25 & $<0.02$ & $<0.01$ & 0.07 & 0.13 & 0.14 & 0.15 \\
\hline$S$ & 583 & 750 & 828 & 878 & 912 & 903 & 864 & B24 \\
\hline Si & 24.1 & 23.0 & 22.2 & 20.8 & 19.0 & 18.5 & 16.9 & 15.8 \\
\hline $\mathrm{Sr}$ & 1.15 & 1.23 & 1.35 & 1.35 & 1.29 & 1.16 & 1.00 & 0.89 \\
\hline $\mathrm{Cl}$ & 30 & 32 & 34 & 34 & 34 & 32 & 32 & 38 \\
\hline$F$ & 2.5 & 2.9 & 3.1 & 3.1 & 3.5 & 3.6 & 3.4 & 4.3 \\
\hline $\mathrm{NO}_{3}$ & 41 & 28 & 17 & 7.7 & 1.9 & $<1$ & $<1$ & N.D. \\
\hline $\mathrm{SO}_{4}$ & 1,700 & 2,100 & 2,300 & 2,600 & 2,800 & 2,600 & 2,500 & 2,200 \\
\hline
\end{tabular}

Trace Metals (ppm)

$\begin{array}{lrrrrrrrr}\text { As } & <0.02 & <0.02 & <0.02 & <0.02 & <0.02 & <0.02 & <0.02 & <0.02 \\ \text { Cd } & <0.02 & 0.02 & <0.01 & 0.01 & 0.01 & 0.01 & 0.01 & <0.01 \\ \mathrm{Ce} & <0.06 & 0.38 & <0.06 & <0.06 & <0.06 & 0.05 & 0.14 & 0.17 \\ \mathrm{Co} & 0.13 & 0.14 & 0.16 & 0.15 & 0.18 & 0.19 & 0.22 & 0.18 \\ \mathrm{Cr} & <0.01 & <0.01 & <0.01 & <0.01 & <0.01 & <0.01 & <0.01 & <0.01 \\ \mathrm{Cu} & <0.02 & <0.02 & <0.02 & <0.02 & <0.02 & <0.02 & <0.02 & <0.02 \\ \mathrm{Mo} & <0.02 & <0.02 & <0.02 & <0.02 & <0.02 & <0.02 & <0.02 & <0.02 \\ \mathrm{Ni} & 0.31 & 0.42 & 0.39 & 0.42 & 0.43 & 0.39 & 0.35 & 0.32 \\ \mathrm{~Pb} & <0.02 & <0.02 & <0.02 & <0.02 & <0.02 & <0.02 & <0.02 & <0.02 \\ \mathrm{Se} & <0.02 & <0.02 & <0.02 & <0.02 & <0.02 & <0.02 & <0.02 & <0.02 \\ \mathrm{~V} & <0.03 & 0.03 & <0.03 & <0.03 & <0.03 & <0.03 & <0.03 & <0.03 \\ \mathrm{Zn} & 2.78 & 2.44 & 2.43 & 2.22 & 1.75 & 2.16 & 1.70 & 1.62 \\ \mathrm{Zr} & <0.01 & 0.02 & <0.01 & <0.01 & <0.01 & <0.01 & <0.01 & <0.01\end{array}$

Radionuclides

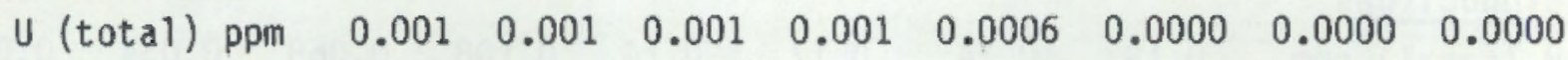

(a) N.D. = Not Determined 
TABLE B.7. Chemical Analysis of Effluent Solutions from Leaching Column No. 1, Tailings Mix I, Produced from Tailings Samples $1,2,3,4$, and 5

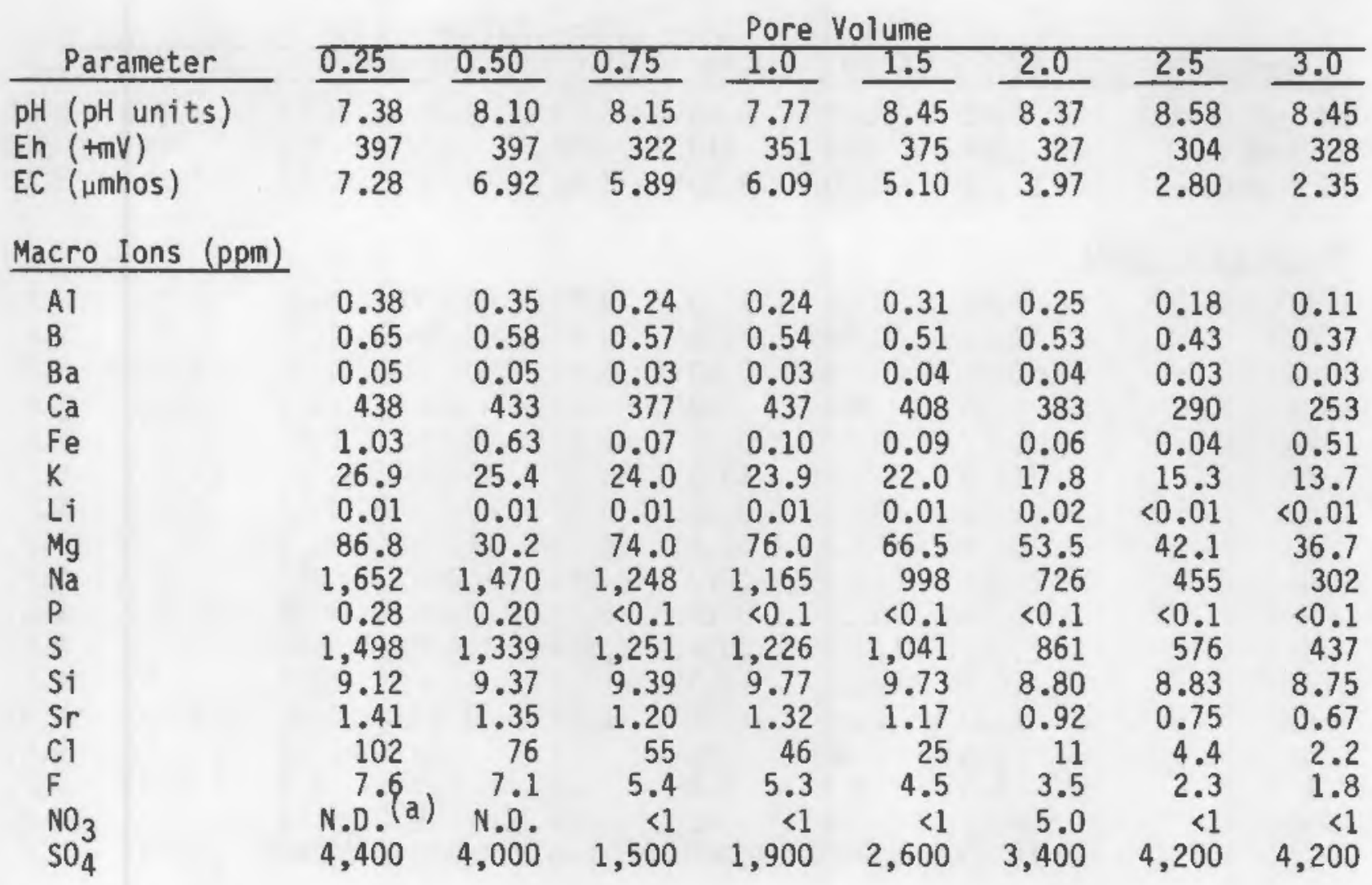

Trace Metals (ppm)

$\begin{array}{lrrrrrrrr}\text { As } & 0.41 & 0.53 & 0.42 & 0.60 & 0.62 & 1.14 & 1.05 & 1.10 \\ \text { Cd } & <0.01 & <0.01 & <0.01 & <0.01 & <0.01 & <0.01 & <0.01 & <0.01 \\ \text { Ce } & 0.22 & 0.15 & 0.15 & 0.10 & 0.20 & 0.39 & 0.07 & 0.04 \\ \text { Co } & 0.52 & 0.59 & 0.34 & 0.44 & 0.44 & 0.30 & 0.22 & 0.16 \\ \text { Cr } & <0.01 & <0.01 & <0.01 & <0.01 & <0.01 & <0.01 & <0.01 & <0.01 \\ \text { Cu } & 0.02 & <0.02 & <0.02 & <0.02 & <0.02 & <0.02 & <0.02 & <0.02 \\ \text { Mo } & 0.49 & 0.48 & 0.43 & 0.43 & 0.44 & 0.36 & 0.33 & 0.34 \\ \text { Ni } & 1.22 & 0.92 & 0.75 & 0.78 & 0.67 & 0.54 & 0.34 & 0.30 \\ \text { Pb } & <0.02 & <0.02 & <0.02 & <0.02 & <0.02 & <0.02 & <0.02 & <0.02 \\ \text { Se } & <0.02 & <0.02 & <0.02 & <0.02 & <0.02 & <0.02 & <0.02 & <0.02 \\ \text { V } & 0.04 & 0.03 & 0.03 & 0.02 & 0.03 & 0.03 & 0.01 & 0.01 \\ \text { Zn } & 0.02 & 0.03 & <0.01 & <0.01 & 0.61 & 0.66 & 0.50 & 0.46 \\ \text { Zr } & 0.01 & 0.01 & 0.01 & <0.01 & 0.02 & 0.16 & <0.01 & <0.01\end{array}$

Radionuclides

$\begin{array}{lllllllll}U(\text { total) } \mathrm{ppm} & 17.00 & 13.50 & 12.50 & 17.30 & 8.85 & 10.40 & 4.62 & 3.41\end{array}$

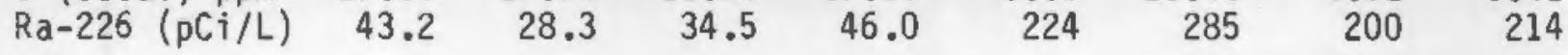

(a) N.D. = Not Oetermined 
TABLE B.8. Chemical Analysis of Effluent Solutions from Leaching Column No. 2, Tailings Mix II, Produced from Tailings Samples 1 and 4

\begin{tabular}{|c|c|c|c|c|c|c|c|c|}
\hline \multirow[b]{2}{*}{ Parameter } & \multicolumn{8}{|c|}{ Pore Volume } \\
\hline & 0.25 & 0.50 & 0.75 & 1.0 & 1.5 & 2.0 & 2.5 & 3.0 \\
\hline ts) & 7.63 & 7.95 & 8.40 & 8.54 & 8.37 & 8.13 & 8.48 & 9.03 \\
\hline Eh $(+m V)$ & 284 & 324 & 313 & 330 & 391 & 323 & 364 & 342 \\
\hline EC (umhos) & 11.31 & 9.80 & 9.10 & 8.66 & 6.69 & 4.12 & 2.71 & 3.11 \\
\hline
\end{tabular}

Macro Ions (ppm)

\begin{tabular}{|c|c|c|c|c|c|c|c|c|}
\hline Al & 0.85 & 0.75 & 0.73 & 0.70 & 0.63 & 0.82 & 0.20 & N.D. (a \\
\hline$B$ & 0.62 & 0.56 & 0.55 & 0.56 & 0.49 & 0.38 & 0.34 & N.D. \\
\hline $8 a$ & 0.04 & 0.03 & 0.03 & 0.03 & 0.02 & 0.03 & 0.02 & N.O. \\
\hline $\mathrm{Ca}$ & 415 & 353 & 382 & 383 & 295 & 173 & 95.7 & N.D. \\
\hline $\mathrm{Fe}$ & 0.52 & 0.14 & 0.15 & 1.11 & 2.45 & 1.93 & 0.77 & N.O. \\
\hline $\mathrm{k}$ & 46.8 & 42.2 & 40.3 & 36.29 & 30.19 & 21.45 & 14.28 & N.O. \\
\hline Li & 0.01 & 0.01 & 0.02 & 0.01 & $<0.01$ & 0.01 & $<0.01$ & N.0. \\
\hline $\mathrm{Mg}$ & 82.8 & 72.3 & 69.8 & 64.02 & 47.19 & 25.0 & 13.2 & N.O. \\
\hline $\mathrm{Na}$ & 2,891 & 2,499 & 2,373 & 2,245 & 1,703 & 993 & 637 & N.O. \\
\hline P & 0.38 & 0.37 & 0.28 & $<0.10$ & 0.28 & 0.30 & 0.21 & N.O. \\
\hline S & 2,277 & 1,971 & 1,894 & 1,864 & 1,402 & 784 & 430 & N.D. \\
\hline Si & 10.5 & 10.6 & 10.6 & 10.7 & 10.5 & 10.7 & 9.5 & N.D. \\
\hline $\mathrm{Sr}$ & 1.33 & 1.14 & 1.16 & 1.07 & 0.82 & 0.46 & 0.25 & N.0. \\
\hline Cl & 118 & 92 & 76 & 53 & 28 & 11 & 3.7 & N.O. \\
\hline $\mathrm{F}$ & 1.3 & 9.4 & 8.8 & 8.1 & 5.9 & 4.4 & 3.9 & N.O. \\
\hline $\mathrm{NO}_{3}$ & N.D. & $<1$ & $<1$ & $<1$ & 5 & 4 & 3 & N.D. \\
\hline $\mathrm{SO}_{4}$ & 7,200 & 5,800 & 5,500 & 5,100 & 4,000 & 2,200 & 1,200 & N.0. \\
\hline
\end{tabular}

Trace Metals (ppm)

\begin{tabular}{|c|c|c|c|c|c|c|c|}
\hline As & 0.79 & 0.77 & 0.73 & 2.87 & 3.02 & N.D. & N.O. \\
\hline Cd & $<0.01$ & $<0.01$ & $<0.01$ & $<0.01$ & $<0.01$ & N.O. & N.O. \\
\hline $\mathrm{Ce}$ & 0.17 & 0.22 & 0.17 & 0.03 & 0.02 & N.D. & N.O. \\
\hline Co & 0.47 & 0.39 & 0.36 & 0.38 & 0.24 & N.0. & N.D. \\
\hline $\mathrm{Cr}$ & $<0.01$ & $<0.01$ & $<0.01$ & $<0.01$ & $<0.01$ & N.D. & N.D. \\
\hline $\mathrm{Cu}$ & $<0.02$ & $<0.02$ & $<0.02$ & $<0.02$ & 0.05 & N.D. & N.O. \\
\hline Мo & 3.43 & 3.40 & 3.01 & 2.94 & 3.03 & N.O. & N.D. \\
\hline $\mathrm{Pb}$ & $<0.02$ & $<0.02$ & $<0.02$ & $<0.02$ & $<0.02$ & N.O. & N.O. \\
\hline $\mathrm{Se}$ & $<0.02$ & $<0.02$ & $<0.02$ & $<0.02$ & $<0.02$ & N.D. & N.O. \\
\hline$v$ & 0.07 & 0.06 & 0.06 & 0.05 & 0.04 & N.O. & N.D. \\
\hline $\mathrm{Zn}$ & 0.01 & 0.01 & 0.91 & 0.52 & 0.41 & N.O. & N.D. \\
\hline $\mathrm{Zr}$ & 0.01 & 0.01 & 0.01 & 0.01 & $<0.01$ & N.D. & N.D. \\
\hline
\end{tabular}

Radionuclides

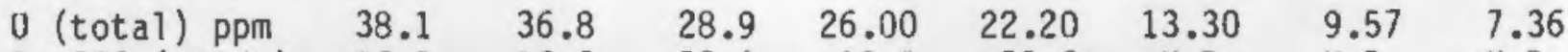

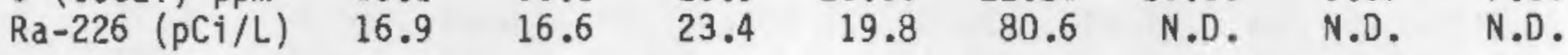

(a) N.D. = Not Determined 


\section{DISTRIBUTION}

No. of

Copies

\section{OFFSITE}

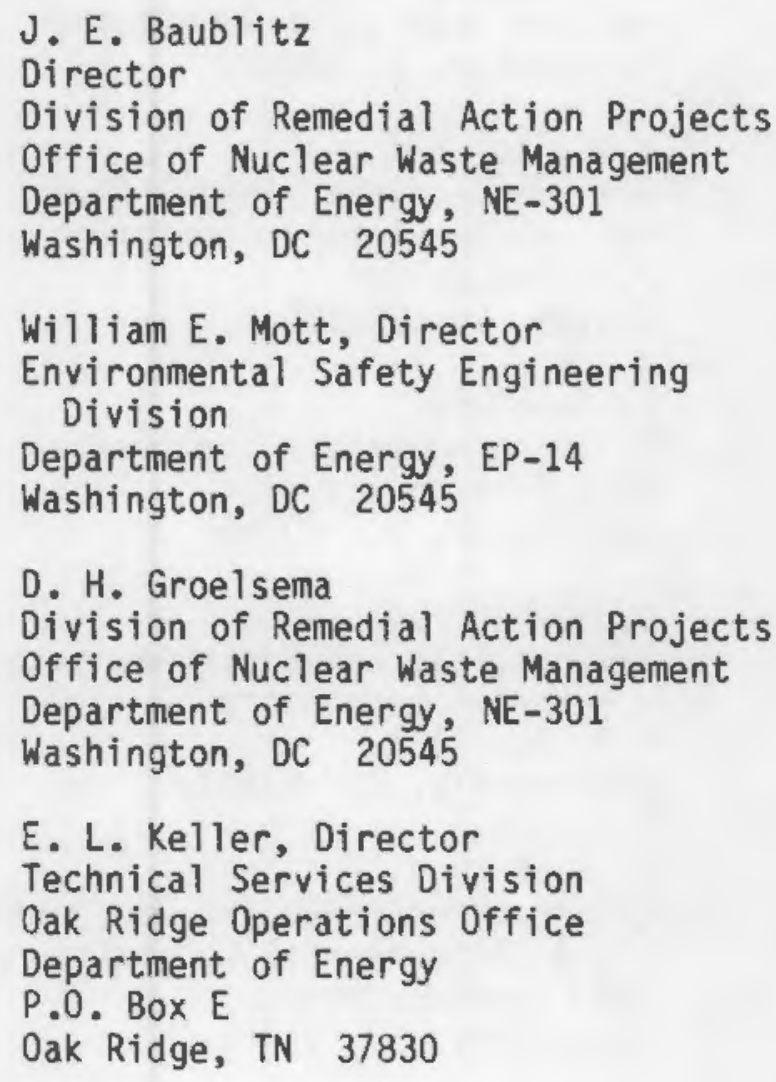

M. L. Matthews, Project Engineer Uranium Mill Tailings Project Office Department of Energy Suite 1700 5301 Central Ave. NE Albuquerque, NM 87108
No. of

Copies

\author{
J. A. Morley \\ Project Manager \\ Uranium Mill Tailings Project Office \\ Department of Energy \\ Suite 1700 \\ 5301 Central Ave. NE \\ Albuquerque, NM 87108 \\ Office of the Assistance Manager for \\ Energy Research and Development \\ Oak Ridge Operations Office \\ Department of Energy \\ P.0. Box E \\ Oak Ridge, TN 37830 \\ M. G. White \\ Division of Remedial Action Projects \\ Office of Nuclear Waste Management \\ Department of Energy, NE-301 \\ Washington, DC 20545 \\ 27 DOE Technical Information Center \\ B. Rawles \\ Battelle Memorial Institute \\ Office of Nuclear Waste Isolation \\ 505 King Avenue \\ Columbus, $\mathrm{OH} 43201$ \\ D. A. Emilia \\ Advanced Technology Division \\ Bendix Field Engineering Corp. \\ P.0. Box 1569 \\ Grand Junction, CO 81502 \\ J. D. Nelson \\ Professor, Program Leader \\ Colorado State University \\ Fort Collins, CO 80523 \\ F. W. Whicker \\ Radiology Radiation \\ Biology Department \\ Colorado State University \\ Fort Collins, CO 80521
}


No. of

Copies

S. Lichtman

Criteria and Standards Division Office of Radiation Programs

Environmental Protection Agency Washington, DC 20460

R. F. Overmyer

Ford Bacon and Davis

P.0. Box 8009

Salt Lake City, UT 84108

K. R. Krishnan

Program Manager

Jacobs Engineering Group, Inc.

Suite 1700

5301 Central Ave. NE

Albuquerque, NM 87108

2 W. Mason

Jacobs Engineering Group, Inc.

Suite 1700

5301 Central Ave. NE

Albuquerque, NM 87108

20 R. Petersen

Document Control

Jacobs Engineering Group, Inc.

Suite 1700

5301 Central Ave. NE

Albuquerque, NM 87108

T. N. Narasimhan

Lawrence Berkeley Laboratory

Berkeley, CA 94720

Chief

Uranium Recovery License Branch

Mail Station 483-SS

Nuclear Regulatory Commission

Washington, OC 20555

G. Gnugnoli

Nuclear Regulatory Commission

Mail Station 2230-SS

Washington, DC 20555
No. of

Copies

W. A. Nixon

Office of Nuclear Materials, Safety and Safeguards

Mail Station 396-SS

Nuclear Regulatory Commission

Washington, DC 20555

R. 0. Smith

Uranium Recovery Field Office

Nuclear Regulatory Commission

P.0. Box 25325

Denver, C0 80225

F. Swanberg

Nuclear Regulatory Commission

Mail Station 1120-SS

Washington, DC 20555

0. D. Markham

Radiological and Environmental

Sciences Laboratory

P.0. Box 2108

Idaho Falls, ID 83401

K. Bush

Research Institute for Geochemistry and Environmental Chemistry

2693 Commerce Road

Rapid City, SD 57701

V. C. Rogers

Rogers \& Associates Engineering

P.0. Box 330

Salt Lake City, UT 84110

\section{ONSITE}

Richland Operations Office

H. E. Ranson/J. C. White 
No. of

Copies

36 Pacific Northwest Laboratory

P. A. Beedlow

J. L. Buelt

M. E. Dodson (10)

J. L. Downs-Berg

D. W. Oragnich

M. G. Foley

J. S. Fruchter

H. 0. Freeman

G. W. Gee (2)

J. N. Hartley

P. C. Hays

B. E. Opitz

S. R. Peterson

J. V. Robinson

R. J. Serne (3)

J. A. Stottlemyer

N. Wogman

Publishing Coordination (2)

Technical Information (5) 
